\title{
Turizm İşletmelerinde Liderlik Tarzıyla İşten Ayrılma Niyeti İlişkisinde Duygu İkliminin Aracılık Etkisi
}

\author{
The Mediation Effect of Emotional Climate in the Relationship of the Leadership \\ and Employee Withdrawal Intention in the Tourism Establishments
}

\section{Arş. Gör. Seray Gülertekin Genç - Prof. Dr. Murat Gümüş}

Başvuru Tarihi: 15.03 .2016

Kabul Tarihi: 18.05.2017

\section{Öz}

Bu araştırmanın amacı, turizm işletmelerindeki duygu iklimi ve liderlik tarzının işten ayrılma niyeti üzerindeki etkisini belirlemektir. Bu etkiyi belirlemek amaciyla Alanya'daki konaklama işletmelerinde, yiyecek içecek işletmelerinde ve seyahat acentalarında yöneticilerin ve işgörenlerin katıldiğı bir alan araştırması yapılmıştır. Turizm işletmelerinde duygu iklimi, liderlik tarzları ve işten ayrılma niyet düzeylerini ölçmek için daha önce geliştirilen ölçekler kullanılmıştır. Örnekleme yöntemi olarak kolayda örnekleme yöntemi tercih edilmiştir. Yöneticilerden ve çalı̧sanlardan ulaşılabilen 503'ü araştırmanın örneklemini oluşturmaktadır. Veriler anket tekniği ile yüz yüze ya da internet ortamından toplanmıştır. Veriler, yapısal eşitlik modeli ile analiz edilmiştir. Elde edilen bulgulara göre; turizm işletmelerindeki liderlik tarzının işten ayrılma niyetini etkilemesinde duygu ikliminin aracılık etkisinin olduğu tespit edilmiştir. Araştırmada elde edilen bulgular doğrultusunda çeşitli önerilerde bulunulmuştur.

Anahtar Kelimeler: Duygu İklimi, Liderlik Tarzı, İșten Ayrılma Niyeti, Turizm İşletmeleri

\begin{abstract}
The purpose of this research is to identify the impact of the leadership style and the emotional climate upon withdrawal intention of employees in tourism establishments. A field research was conducted in which the participants consist of employees and managers working in the hotel sector, fooderbeverage establishments and travel agencies in Alanya in order to determine this impact. The items in the scale were taken from the previous developed scales to measure the level of emotional climate, leadership styles and employee withdrawal intention in tourism establisments. The sample of the study comprised of 503 employees and managers based on the convenience sampling method. Data were collected by means of interviews, conducted either faceto-face or online via internet. Data were analyzed by structural equation modeling. According to the results obtained, in the influence of leadership style upon employee withdrawal intention in tourism establishments, emotional climate has been found as the intermediation effect. Various suggestions were presented in the light of the results obtained from the study.
\end{abstract}

Keywords: Emotional Climate, Leadership Styles, Employee Withdrawal Intention, Tourism Establisments

\footnotetext{
Arş. Gör. Seray Gülertekin Genç, Batman Üniversitesi Turizm İşletmeciliği ve Otelcilik Yüksekokulu, seraygulertekin@gmail.com Prof. Dr. Murat Gümüş, Batman Üniversitesi Turizm İşletmeciliği ve Otelcilik Yüksekokulu, muratgumus@yahoo.com

* Bu makale, Seray Gülertekin’in Çanakkale Onsekiz Mart Üniversitesi Sosyal Bilimler Enstitüsü’nde yazılan “Duygu İklimi ve Liderlik Tarzının İşten Ayrılma Niyetine Etkileri: Alanyảdaki Turizm İşletmelerine Yönelik Bir Araştırma” başlıklı yüksek lisans tezinden türetilmiştir.
} 


\section{Giriş}

Son yıllarda işletmelerin üzerinde yoğunlaştı̆̆ 1 en önemli örgüt kaynağı insan ve onun örgüt içinde sergilemiş olduğu davranışlardır. Örgütsel verimliliğin sağlanmasında önemli bir unsur olan işgörenlerin örgüt içindeki verimliliklerinin artırılmasında onların davranışlarını etkileyen sosyo-psikolojik faktörlerin çok iyi bir şekilde analiz edilmeleri gerekmektedir (Yazıcıŏlu, 2009, s. 236). İşgörenlerin davranışları üzerinde etkili olan önemli psikolojik faktörlerden biri de örgüt içindeki duygu iklimidir. Schein (1999, s. 3) duygu iklimini; "müşsterilerin ya da işgörenlerin bir örgüte yeni katıldiklarında veya daha sonra fiziksel yerine duygusal olarak görülen, duyulan ve hissedilen deneyimleri" olarak tanımlamaktadır. Duygu ikliminin olumlu algılanması, işgörenlerin başarı güdülerinde, verimlilik ve etkinliklerinde önemli bir yere sahiptir. Ancak algılar her zaman gerçeği yansıtmaz, algılamayı kişinin eğitimi, deneyimleri, inançları ve kültürü etkilemektedir. Algılar gerçeği değil, onun kavranma biçimini gösterir; bu nedenle duygu ikliminin işgörenler tarafından farklı algılanması doğaldır. Tıpkı aynı nehirde yıkanmak, aynı sularda yıkanmak anlamına gelmediği gibi, aynı örgütsel ortamda bulunmak, duygu ikliminin aynı şekilde algılanmasını sağlamayabilir. Örgütlerde demokratik veya otoriter, destekçi veya engelleyici, güven veren veya güvenilmez, işe veya işgörene yönelik gibi farklı yönetsel anlayışlar, farklı duygu iklim algılamalarına neden olmaktadır. Duygu iklim algısının farklılığı, söz konusu algının yönetilmesi gereğini ortaya koymakta ve burada liderin rolü ortaya çımaktadır.

Liderlerin, işgörenlerin değişen koşullara ve örgüt yapılarına hızla uyum sağlayabilmeleri, değişimi takip edebilmeleri, bulunduğu ortamdan memnuniyet duyabilmeleri, işine karşı duygusal aidiyet hissedebilmeleri ve işten ayrılma niyetlerini azaltabilmek için, duyguları iyi tanıyabilmeleri, duyguların davranışları nasıl etkileyebildiği, duyguların ifade ediliş biçimleri ve duyguların nasıl yönlendirileceği konularında daha donanımlı olmalarını zorunlu kilmaktadır (Töremen ve Çankaya, 2008, s. 34). Bu süreçte duygu ikliminin önemi giderek artmakta ve olumlu duygu iklimleri (umut, dayanışma, kuruma güven ve sevinç) bireyler ve örgütler için önemli bir sosyal sermayeyi oluşturmaktadır.

Turizm faaliyetlerinde, örgütlerin merkezinde insan yer almaktadır. Örgütün işlerliğinin mükemmelleşti- rilmesi, örgütün parçası olan insanların profesyonelce çalışmalarına bağlı olmaktadır (Akoğlan Kozak 2012: 55). Turizm faaliyetlerinde en doğru davranışların tespit edilebilmesi için uluslararası geçerliliği olan somut kurallardan bahsetmek zordur. Ancak örgütlerin kendisi, kendi kurallarını geliştirmekte ve örgütlerin tüm ayakları bu kurallara uygun hareket etmektedir. Turizm, bir memnuniyet ve doygunluk faaliyetidir. Kişilerin, başka kişilere en iyi hizmeti sunabilmeleri için kendi çalışma ortamlarındaki duygu iklimini olumlu algılaması ve bu çalışma ortamlarından kaynaklanan getirilerin arttırılması gerekmektedir. $\mathrm{Bu}$ bağlamda, "turizm işletmelerinde duygu iklimlerinin liderlik tarzı ve işten ayrılma niyeti arasında ilişki var mıdır?" sorusu bu araştırmanın problemini oluşturmaktadır.

Araştırmada, duygu ikliminin liderlik tarzı ile işten ayrılma niyeti arasındaki etkisini ortaya koymak amaçlanmıştır. Bu araştırma, diğer sektörlerden farklı bir kültüre sahip olan ve çıtıların insan performansına dayalı olduğu turizm işletmelerinde gerçekleştirilecektir. Bu bağlamda, turizm işletmeleri gibi merkezinde insanın yer aldığı sektörlerde duygu iklimini öğrenmek ve buna yönelik önlemler almak önem arz etmektedir. Ayrica bu konuda alanda sinırlı sayıda çalışma olması ve ulaşılan kaynaklarda turizm işletmelerinde bu konuya ilişkin bir araştırmaya rastlanamaması çalışmanın özgün yönünü ortaya koymaktadır. Örgütteki duygu ikliminin bilinmesi, liderlerin bu konulara da dikkat ederek çalışanları etkin yönetmede fikirler vereceği aynı zamanda çalışanın işten ayrılma niyetini etkileyeceğinden gerek alana gerekse literatüre katkı sağlayacağı düşünülmektedir.

\section{Kavramsal Çerçeve}

\section{Duygu İklimi}

İklim kavramı literatürde iki farklı anlamda ele alınmıştır; her iki anlamda da örgütsel iklimin her şeyi kapsadığına dair vurgu yapmaya yardım etmektedir. Yaygın olarak kullanılan ilk anlamıyla iklim; ortak bir kavrayış, bir durum karşısında bireylerin gösterdiği ortak bir tepki şeklinde ifade edilmiştir. İkinci anlamı ise, bireylerin davranışları üzerinde etkisi olan durumlar dizisini ifade etmektedir (Denision, 1990, s. 24). Benzer bir şekilde duygu iklimi de örgüt ikliminin bir türüdür. Koys ve DeCotiis (1991, s. 266) duygu iklimini; "bir örgütteki örgüt üyeleri tarafın- 
dan paylaşılan deneyime dayalı, çok boyutlu bir algı" olarak tanımlamışlardır. Duygu iklimi, örgüt içinde bulunan bireylerin davranışlarını ve duygularını etkileyen ve onlardan etkilenen, somut olarak gözle görülüp elle tutulamayan, ancak örgüt içindeki bireylerce hissedilip algılanabilen, bazen kişilerin jest ve mimikleriyle somutlaşabilen (suratın asılması) ve bütün bu özellikleri içine alan psikolojik bir terim olduğu söylenmektedir (Ruiz, 2007, s. 290; Tran, 1998, s. 101).

Duygu iklimi ilk olarak Payne ve Pugh (1976) tarafından ortaya konulmuştur. Araştırmacılar duygu iklimini örgüt içerisindeki hiyerarşinin, teknolojinin, kuralların ve düzenlemelerin; insanların davranışlarını, düşüncelerini ve hislerini etkilediğini belirtmişlerdir. Yani duygu iklimi örgütsel yapının bir sonucudur. Daha sonra kavramla ilgili başka çalışmalar da olmuştur. Schneider ve Reichers $(1983$, s. 26) da Payne ve Pugh'un (1976) çalışmalarına ek olarak örgütsel yapının yanında bireylerin kendi kişiliklerinin de duygu iklimini oluşturmada etkili olduğunu vurgulamışlardır. Schneider ve Reichers (1983), Payne ve Pugh'un (1976) yaptığı iklim çalışmalarında bazı eksikliklerin olduğunu belirtmişlerdir.

Duygu iklimi; durumsal olayların bireysel algılarına işaret eden bir kavramdır. Bu bağlamda, duygu ikliminin öznel olduğu söylenebilir, ancak örgüt içerisindeki takım üyeleri var olan iklimi paylaşma eğilimi gösterebilir. Bir kişi, düşüncelerini, hislerini ve davranışlarını değerlendirmek amacıyla algılarını kullanmaktadır (Spiess, 2011, s. 11). Sonuçta, algılar gerçeği değil, onun kavranma biçimini gösterir; bu nedenle iklimlerin işgörenler tarafından farklı algılanması da doğaldır (Tutar ve Altınöz, 2007, s. 196).

Örgütlerde duygu iklimi üzerine yazında birçok araştırma (Spiess, 2011; De Rivera ve Yurtsever, 2010; Yurtsever ve De Rivera, 2010; Ruiz, 2007; Paez vd., 2007; Rime, 2007; Cole vd., 2006) bulunmasına karşın, duygu ikliminin henüz net bir sinıflandırılması ortaya konulamamıştır. Diğer bir deyişle, örgütlerdeki duygu ikliminin hangilerinin çalışanlar üzerinde daha etkili olduğunu belirlemeye yönelik araştırmalarda ortak bir fikir oluşturulacak sonuçlar elde edilememiştir. Ruiz (2007) duygu iklimini umut, dayanışma, güven, sevinç, korku, öfke, üzüntü, suçluluk, emniyetsizlik, istikrarsızlık, aşağılanma ve yalnızlık olarak sınıflandırmıştır. Başka bir çalışmada De Rivera ve Yurtsever (2010) ise, duygu iklimini güven, umut ve güvenlik olmak üzere üç boyutta incelemişlerdir.
İşyerinde bir iletişim örüntüsü içerisindeki işgörenler, olayların hem yaratıcısı hem de aktörüdür. $\mathrm{Bu}$ bağlamda işgörenlerin davranışlarında somutlaşan; işyerinin iletişim tarzı, yönetim biçimi, kültürü, normları, paylaşılan bir atmosferi oluşturur (Gök ,2009, s. 589). Duygu iklimi olarak adlandırabileceğimiz bu atmosfer, işgörenlerin duygularını, davranışlarını dolayısıyla da performanslarını ve motivasyonlarını etkilemektedir.

\section{Liderlik Tarzları}

İnsan, sosyal bir varlıktır. İnsanoğlunun toplumsal bir varlık olarak yaşamaya başlamasından itibaren, belli bir grup içinde yaşaması ve bu grupları örgütlemesi söz konusudur. Ancak; insanlar grup halinde yaşayan sosyal nitelikli canlılar oldukları kadar, oluşturduklar1 grupları yönetecek ve hedeflerine götürecek liderlere de ihtiyaç duyan varlıklardır (Eren 2012). Robbins ve Judge (2012, s. 376) liderliği "amaçların veya vizyonun başarılmasına yönelik grubu etkileyebilme yetenę̆gi" olarak tanımlamaktadırlar.

Turizm sektöründe artan rekabet ortamında başarılı bir organizasyonel hedef, işgörenlerin performansını geliştirme ve hizmet kalitesini arttırmada, yeni yönetim metotlarını benimsemek zorunlu hale gelmiştir. Turizm işletmelerinde liderliğin anlaşılması ve biçimlendirme çabaları, liderin verimliliği, çalışanların davranışları ve performansları da dahil olmak üzere birçok önemli organizasyonel çıttıları da etkilemektedir. Turizm işletmelerinde liderlik hizmet kalitesinin sağlanmasına yönelik belirli stratejilerin ve politikaların uygulanabilmesinin önemli unsurlarından biridir (Güzel, 2009, s. 124).

Liderler tarafından seçilen ve yönetim anlayışlarını yansıtan liderlik tarzları, her şeyden önce lider statüsündeki kişinin çalışanları ve grubundaki etkinliğini gösterecektir. Bu nedenle liderin seçtiği ve yönetim anlayışını yansıtacak liderlik tarzı seçiminden avantaj-dezavantaj olasılıklarının sonuçları, çalışanların ve işin yapısının uygunluğu, grubun hedef ve amaçlarına ne kadar katkıda bulunacağı göz önünde bulundurularak seçilmelidir. Uygun liderlik tarzının seçimi, hem bireylerin iş motivasyonunu arttıracak hem de grubun organizasyonel amaçlarını gerçekleştirmesini sağlayacaktır (Yeşilyurt, 2007, s. 37).

Liderlik tarzı, liderin örgütsel amaçlarını gerçekleştirmek, grubunu ve iş ortamını, örgütün amaçları ve 
işgörenlerin motivasyonu ve örgüt içerisindeki duygu iklimini dikkate alarak seçmiş olduğu davranış biçimidir. Herhangi bir tarzı belirlemiş olan lider, karşılaştığı durumlar karşısında göstereceği davranışlar, benimsemiş olduğu yaklaşımın bir yansımasıdır (Hicks ve Gullert, 1981, s. 234).

Liderlerin gösterdikleri davranışlara ilişkin olarak pek çok sınıflandırma yapılmaktadır. Ancak bu liderlik davranışları iki temel grup altında toplanabilir. Bunlar; geleneksel liderlik davranışları ve çağdaş liderlik davranışlarıdır. Geleneksel liderlik davranış tarzı, liderin izleyiciler ile veya yönettiği grupla olan ilişkilerindeki tutum ile ilgilidir. Bu davranış tarzlarından en çok bilinenleri; otokratik, demokratik katılımcı ve tam serbesti tanıyan liderliktir. 1978 yılından itibaren yönetim ve liderlik alanında geleneksel liderlik davranışları yanında, Burns ve Bass'ın yaptıkları araştırmalarda yeni bir ayrım yapılmış ve bu ayrım, geleneklere ve geçmişe bağlı Transaksiyonel Liderlik (işe yönelik liderlik) ile geleceğe, yeniliğe, değişime ve reforma dönük harekete geçirici-dönüştürücü-yenilikçi veya Transformasyonel Liderlik (değişimci liderlik) tarzlarıdır (Özer, 2007, s. 29-30). Liderlik tarzları, sonuçları açısından alanyazında yoğun olarak incelenen bir kavramdır (Mullins, 1998; Woo, 1998; İnce 2013; Güzel ve Akgündüz, 2011; Tütüncü ve Akgündüz, 2012; Çelik, 2011; Tekin ve Ehtiyar, 2011; Yavuz, 2009).

Duygu iklimi yönetiminde, ne tür bir liderlik biçimi gösterileceğini, örgütün hangi tip iklime sahip olduğu belirlemektedir. Diğer bir deyişle, duygu iklimi tipiyle liderlik biçimi, birbirleri ile yakından ilişkilidir. Olumlu duygu iklimlerinde lider çalışanların görüşlerini dinlemekte ve dikkate almaktadır. Olumsuz duygu iklimlerinde ise lider, çalışanlarına ne yapmaları gerektiğini söylemektedir (Pheysey, 1993, s. 150-155). Spiess (2011) hizmet işletmelerinde duygu iklimiyle ilgili yapmış olduğu çalışmada, liderlik tarzının örgüt içerisindeki duygu ikliminin şekillenmesinde önemli bir etkisinin olduğunu tespit etmiştir. Başka bir çalışmada; Unur, Çakıcı ve Duran (2011, s. 135-142) liderlik tarzlarının örgüt içerisindeki güven ortamıla doğrudan ilişkili olduğunu tespit etmişlerdir. Bu bağlamda, başarılı bir lider olmak için, hem işgörenlerin duygularını anlama hem de kendi duygularını etkin kullanma çok önemli olduğu söylenebilir.

\section{İşten Ayrılma Niyeti}

İşten ayrılma niyeti, işgören davranışları ve bu davranışlara bağlı olan faktörler örgütler için önemli bir sorun olma niteliği taşımaktadır. İşgörenlerin yetiştirilmesi örgütler için çok zor olmakta ve örgütler işgörenleri yetiştirmek için para ve zaman harcamaktadır. Bundan dolayı işten ayrılma özellikle turizm odaklı sektörlerde önemli bir maliyet unsuru oluşturmaktadır. Rusbelt ve Rogers (1988, s. 599) işten ayrılma niyetini; "işgörenlerin istihdam koşullarının tatminsiz olmaları durumunda gösterdikleri yıkıcı bir eylem" olarak tanımlamışlardır.

İşten ayrılmalar, gerek işgören gerekse de örgüt açısindan birtakım olumlu ve olumsuz sonuçlar doğurmaktadır. Özellikle performansı düşük olan işgörenlerin ayrıldığı durumlarda, işten ayrılmalarının örgüt için olumlu bir sonuç doğurduğu (George ve Jones, 1996); bununla birlikte, işten ayrılmaların, geride kalan işgörenler için bir kariyer fırsatı (terfi gibi) olduğu ya da o alanda daha nitelikli ya da profesyonel bir bireyin örgüte katılımını sağlayabileceği söylenebilir. $\mathrm{Bu}$ olumlu yanlarının yanında, ișten ayrılmaların, yeni bir işgörenin bulunmasının ve kısa sürede eğitiminin getirdiği güçlükler, geride kalanların yaşadığ 1 mutsuzluk, özellikle mutsuzluk oranının yüksek olması gibi durumlarda örgütün saygınlığının zedelenmesi, önemli projelerin kesintiye uğraması ya da takım çalışmalarının bloke olması gibi olumsuz sonuçları olduğu da belirtilmelidir. Buraya kadar aktarılanların ışı̆̆ı̆ında, işten ayrılmaların, işgörenin kendisi açısından olumsuz sonuçlar doğuracağını; ancak, sonuçların örgüt açısından olumlu ya da olumsuz olmasının ise bu ayrıllğ̆ın işlevselliğine bağlı olacağg söylenebilir (Newstorm ve Davis, 1993).

Liderlik tarzları ile ilgili yapılan araştırmalarda, bu kavramın sonuçlarının; iş tatmini, iş performansı, işten ayrılma niyeti üzerinde etkili olduğu görülmektedir (Smoak, 2008; Riley, 2006; Whittington vd., 2004; Smith, 1999; Telli vd., 2012; Şahin, 2011). Yapılan bu çalışmalarda, dönüştürücü liderlik tarzının işten ayrılma niyetini azalttığı tespit edilmiştir (Smoak, 2008; Whittington vd., 2004).

İşten ayrılma niyetinin örgüt içerisindeki duygu iklimi açısından değerlendirildiğinde; örgüt içerisindeki olumsuz duygu ikliminin işten ayrılma niyeti arasında yakın bir ilişki olduğu ve örgütler tarafından arzu 
edilmeyen bir kavram olduğu görülmektedir. İșten ayrılma niyeti örgütler üzerinde birçok olumsuz sonuçlar doğurabilmektedir. Bu nedenle liderlerin işten ayrılma davranışının en önemli habercisi olan işten ayrilma niyetini önceden sezmeleri gerekmektedir.

Tüm bu değerlendirmeler dikkate alındığında işgörenlerin ruh halini yönetmek ve sağlıklı bir duygu iklimi yaratmakta liderlere önemli görevler düşmektedir. İşgörenlerin duygularının dikkate alındığı bir yapıda liderler, örgütlerin duygu iklimleri hakkında yüksek farkındalık düzeyine sahiptirler; işgörenler bu tür ortamlarda kendilerini örgütlerine ve görevlerine adanmış hissetmektedir. Liderler tarafından bastırılan ve önemsenmeyen duygu iklimleri, sonradan çok ciddi (işten ayrılma niyeti, yeteneksizleşen işgörenler, artan isteksizlik, müşteri şikayetleri vb.) maddi ve manevi kayıplar yaratmaktadır. Bu bağlamda, liderlerin örgüt içerisinde güçlü bir duygu iklimi yaratabilmesi örgüte somut katkılar sunabilir.

\section{Araștırmanın Modeli ve Hipotezleri}

$\mathbf{H}_{1}$ : Isşgörenlerin kendilerinin algıladığ iklimi, işgören odaklı liderlik algılamaları ile işten ayrılma niyetleri arasında aracı rol üstlenir.

$\mathbf{H}_{2}$ :İsgörenlerin çevresinin algiladığ 1 olumlu duygu iklimi, işgören odaklı liderlik algılamaları ile işten ayrılma niyetleri arasında aracı rol üstlenir.
$\mathbf{H}_{3}:$ İsgörenlerin kendilerinin algiladığı olumlu duygu iklimi, görev odaklı liderlik algılamaları ile işten ayrılma niyetleri arasında aracı rol üstlenir.

$\mathbf{H}_{4}$ :İşgörenlerin kendilerine yönelik olumlu duygu iklimleri, değişim odaklı liderlik algılamaları ile işten ayrilma niyetleri arasında aracı rol üstlenir.

$\mathbf{H}_{5}$ :Işgörenlerin kendilerine yönelik olumsuz duygu iklimi algılamaları, işgören odaklı liderlik algılamaları ile işten ayrılma niyetleri arasında aracı rol üstlenir.

$\mathbf{H}_{6}$ : İşgörenlerin çevrelerine yönelik olumsuz duygu iklimi algılamaları, işgören odaklı liderlik algılamaları ile işten ayrılma niyetleri arasında aracı rol üstlenir.

$\mathbf{H}_{7}$ :İşgörenlerin kendilerinin algıladığı olumsuz duygu iklimi, görev odaklı liderlik algılamaları ile işten ayrılma niyetleri arasında aracı rol üstlenir.

$\mathbf{H}_{s}:$ İsgörenlerin çevresinin algıladığ olumsuz duygu iklimi, görev odaklı liderlik algılamaları ile işten ayrılma niyetleri arasında aracı rol üstlenir.

$\mathbf{H}_{9}$ :İşgörenlerin kendilerinin algıladığı olumsuz duygu iklimi, değişim odaklı liderlik algılamaları ile işten ayrılma niyetleri arasında aracı rol üstlenir.

$\mathbf{H}_{10}$ : İşgörenlerin çevresinin algıladığı olumsuz duygu iklimi, değişim odaklı liderlik algılamaları ile işten ayrılma niyetleri arasında aracı rol üstlenir.

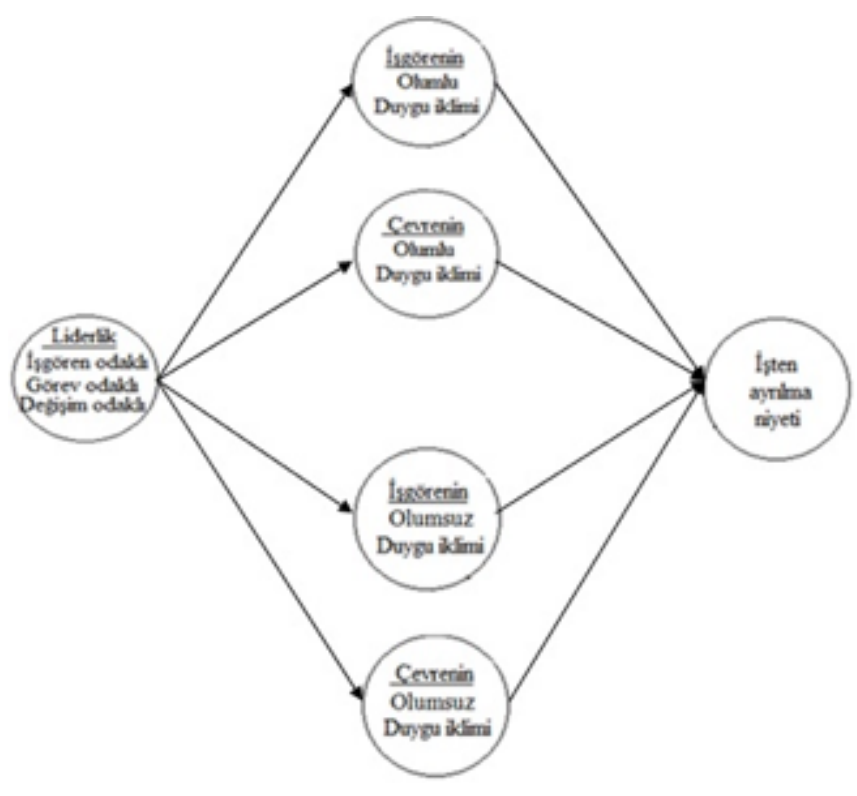

Şekil 1. Araştırma Modeli 


\section{Araştırmanın Yöntemi}

$\mathrm{Bu}$ araştırmanın çalışma evrenini, Antalya ilinin Alanya İlçesi sınırları içerisinde yer alan 4 ve 5 yıldızlı konaklama işletmelerinin, A grup seyahat acentelerinin ve bakanlık belgeli 1. sinıf yiyecek-içecek işletmelerinin yöneticileri ve çalışanları kapsamaktadır. Evrende yer alan istatistik birimlerinin yer aldığ 1 örgütlerin tercih edilmesinin nedeni bu örgütlerin 3 ve daha az yıldıza sahip konaklama işletmeleri, B ve C Grubu seyahat acentaları ve belediye belgeli yiyecek-içecek işletmelerine nazaran kurumsallığın profesyonel bir yönetim anlayışının ve bunun paralelinde duygu iklimine yönelik değerlerin daha yerleşik bir durumda olduğu düşüncesidir. Araştırmanın örneklemi Alanya'da kolayda örnekleme yöntemi ile seçilmiş 50 adet 4 ve 5 yıldızlı otel işletmesi, 50 adet A grubu seyahat acentesi ve 1 adet bakanlık belgeli 1.sınıf yiyecek-içecek işletmesinin 503 çalışanından oluşmaktadır.

Araştırmada veriler elde edilirken evrende yer alan tüm örgütlere ulaşılmaya çalışılmış ancak örneklemde yer alan örgütlere ulaşılmış ve ulaşılan örgütlerde yer alan istatistik birimleri ile yüz yüze görüşülerek anket formlarının doldurulması sağlanmıştır. Zaman ve mali kısıtlardan dolayı kimi örgütlere anket formlarından bırakılmış ve daha sonra da formlar toplanmıştır. Ayrıca yüz yüze ulaşılamayan ya da anket formu dağıtılamayan örgütlere örgütlerden gerekli izin ve bilgiler alınarak elektronik posta ile ulaşılmaya çalışılmıştır. Sonuç olarak yönetici ve çalışanlara toplam 570 anket ulaştırılmıs ve bunlardan 203'ü maille olmak üzere 540 anket dönüş sağlanmıştır. Hatalı ve eksik doldurulan anket formları değerlendirilmeye alınmamış ve 503 yönetici ve çalışanın anket formlarına verdiği bilgiler değerlendirmeye alınmıştır.

\section{Veri Toplama Araçları}

Araştırma verilerinin toplanması amacıyla anket formunda üç ölçek kullanılmıştır. Liderlik Tarzları için, Tengilimoğlu (2005) tarafından Türkçeye uyarlanan Ekvall ve Arvonen (1991) tarafından geliştirilen ölçekten yararlanılmıştır. Ölçek işgören odaklı liderlik, görev odaklı liderlik ve değişim odaklı liderlik boyutlarından ve toplam 36 maddeden oluşmaktadır.

Duygu iklimi ölçeği, Ruiz (2007) tarafından geliştirilen ölçekten yararlanılmıştır. Ölçek toplam 12 sorudan oluşmakta; örgüt içindeki olumlu ve olumsuz duygu iklimini ölçmektedir. 4 madde (umut, dayanışma, kuruma güven ve sevinç) olumlu duygu iklimini; 8 madde (korku, öfke, üzüntü, suçluluk, emniyetsizlik, istikrarsızlık, aşağılanma ve yalnızlık) olumsuz duygu iklimini ölçmektedir.

İșten ayrılma niyetini ölçmek için Cammann vd. (1979) tarafından geliştirilmiş ve üç maddeden oluşan ölçekten yararlanılmıştır. Ölçekler 5'li Likert Ölçeği tipinde olup, (1) "Kesinlikle katılmıyorum", (5) "Kesinlikle katıliyorum"u ifade edecek şekilde derecelendirilmiştir.

Orijinal dili İngilizce olan ölçekler, araştırmacı tarafından Türkçeye, Türkçesi ise başka bir araştırmacı tarafından İngilizceye çevrilmiştir. Bunun nedeni, ölçeklerin Türkçesi ile orijinal dili arasındaki anlamsal doğruluğu sağlamaktır (Van de Vijver ve Hambleton 1996). Karşılaştırma sürecinden sonra ölçeklerin yapılarıyla ilgili sapmaların olmadığı ve orijinal dilindeki anlamıyla çelişmediği doğrulanmıştır. Bu süreçten sonra, ölçeklerin hedef kitle tarafindan anlaşılır olup olmadığı kontrol edilmesi için pilot çalışma uygulanmıştır. Uygulama, Çanakkale'de 4 yıldızlı bir otel işletmesinde rastgele seçilen 30 kişiye yapılmıştır. Sonuç olarak, ankette yer alan her bir ifadenin anlaşılır olduğu tespit edilmiştir. Anket, ilgili alanda uzman üç akademisyen ve iki sektör temsilcinin görüşü alındıktan sonra asıl uygulamaya hazır hale getirilmiştir.

\section{Bulgular}

Turizm işletmelerinde çalışanların duygu iklimi ve liderlik tarzının işten ayrılma niyetine olan etkilerinin araştırıldığı çalışmada örneklem hacmi 503 olarak gerçekleşmiştir. Katılımcıların \%36,6’sı kadın, \%63,4 ise erkektir. Ortalama yaşı $28,07 \pm 2,88$ olarak gerçekleşmiştir. Katılımcıların kurum kıdemlerinin ortalaması 2,88 $\pm 2,44$, meslek k1demlerinin ortalaması da $6,4 \pm 4,45$ olarak bulunmuştur. Eğitimlerine göre mod sınıfının ortaöğretim olduğu, \%63, 8'inin ise bekar olduğu bulunmuştur. Katılımcıların \%42,5 sürekli açı olan işletmelerde, \% 57, 5’i ise sezonluk işletmelerde çalışmaktadır. İ̧̧letmede shift (vardiya) usulü çalışanların oranı \%42,5'dir. Otel işletmesinde çalışanların oranı ise \% 71 olarak hesaplanmış, seyahat işletmesinde çalışanların oranı ise \%26,2 olarak hesaplanmıştır. Çalışanların işletmede pozisyonuna bakıldığında \% 32,7 'sinin yönetici olduğu belirlenmiştir. 
Faktörlere (boyut ya da gizil değişkenlere) yönelik ölçeklerin güvenilirlikleri araştırılmış ve ölçekler güvenilir bulunmuştur. En yüksek güvenirlik işgören odaklı liderlik ölçeğinde elde edilmiş ve Cronbach a istatistiği 0.98 olarak hesaplanmıştır. Benzer şekilde değişim odaklı liderlik ölçeği için 0,966 , kendi algıladığı olumsuz duygu iklimi için 0,961 , çevreye yönelik olumsuz duygu iklimi için 0,957 , görev odaklı liderlik ölçeği için 0,952 , çevreye yönelik olumlu duygu iklimi için 0,949, kendi algıladığı duygu iklimi için 0,948 , işten ayrılma niyeti için 0,946 olarak hesaplanmıştır. Ölçeklerde faktörlere ilişkin en küçük ortalama 2.779 ile kendi algıladığı olumsuz duygu iklimi, en yüksek ortalama ise 3.271 ile görev odaklı liderlik boyutlarında elde edilmiştir.

Araştırmanın temel amaçlarından biri duygu iklimi, liderlik tarzı ve işten ayrılma niyeti arasında bir model oluşturulmasıdır. Bu amaçla da değişkenler arasında yapısal eşitlik modeli uygulanmıştır. Araştırmada öncelikle gizil değişkenler arası ilişkilere yönelik yapısal model kurulmuştur. Kurulan yapısal eşitlik modelinin sinanmasında elde edilen uyum ölçütleri; ; $\chi 2=585$; d.f. $=163 ; \chi 2 / \mathrm{df}=3,58, \mathrm{P}$-value $=0,0000$ RMSEA $=0,072$, $\mathrm{NFI}=0.99, \quad \mathrm{NNFI}=0.99, \quad \mathrm{PNFI}=0,85, \quad \mathrm{CFI}=0.99$, $\mathrm{IFI}=0.99, \mathrm{RFI}=0.99, \mathrm{GFI}=0.90, \mathrm{RMR}=0.058$ olarak elde edilmiştir. Uyum ölçütlerine bakıldığına elde edilen modelin kabul edilebilir olduğu görülmüş ve model Şekil 1 ve Şekil 2'de verilmiştir. Şekil 1 standart çözümü göstermektedir. Şekil 2 ise Şekil l'e yönelik elde edilen yolların anlamlılığını gösteren $t$ istatistiklerini göstermektedir. Duygu iklimine yönelik gizil değişkenler için ilişkilere bakıldığında en yüksek ilişkinin 0,77 ile çevreye yönelik duygu iklimi ile işgören odaklı liderlik tarzı arasında olduğu belirlenmiştir. İşgören odaklı liderlik tarzındaki değişimlerin 0,5929 birimi çevrenin algıladığı duygu iklimini açıklamaktadır. En az ilişki ise -0,14 ile işten ayrılma niyetinden elde edilmiştir. Çevrenin algıladığı duygu iklimi işten ayrilma niyetinde 0,0196 birimlik bir varyansa sahiptir. İşten ayrılma niyetine yönelik model;

İşten ayrılma niyeti $=\mathbf{0 , 2 2}{ }^{*}$ İsgören odaklı liderlik $-0,66^{\star}$ Kendisinin algıladığı duygu iklimi şeklinde yazılabilir.

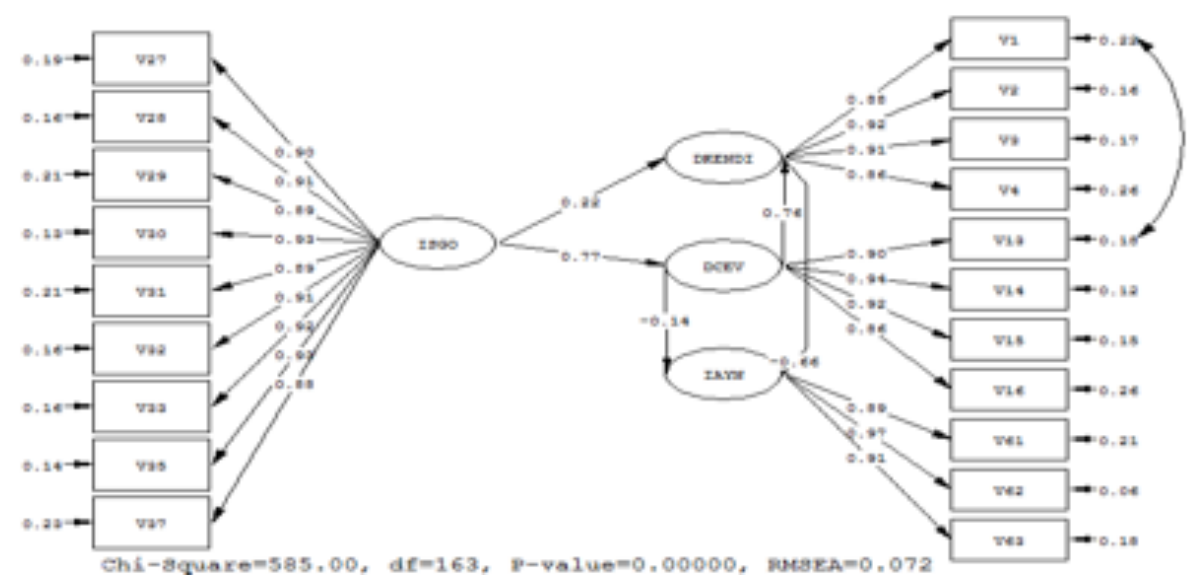

Şekil 2. İsgören Odakı Liderlik Tarzına Yönelik Olumlu Duygu İklimine Illişkin Yapısal Model ve İlişkileri

Gizil değişkenlerle gözlenen değişkenler arasındaki ilişkiler ya da gözlenen değişkenlerin gizil değişkenlerde ilişkilendirildiği modele göre,

- Çalışanların kendilerinin algıladığı olumlu duygu iklimi, işgören liderlik algılamaları ile işten ayrılma niyetleri arasında aracı rol üstlendiği belirlenmiştir. Dolayısıyla $\mathbf{H}_{1}$ desteklenmiştir.
- Çalışanların çevresinin algıladığı olumlu duygu iklimi, işgören odaklı liderlik algılamaları ile işten ayrılma niyetleri arasında aracı rol üstlendiği ile ilgili yeterli kanıt bulunamamıştır. Dolayısıyla $\mathrm{H}_{2}$ desteklenememiştir. 


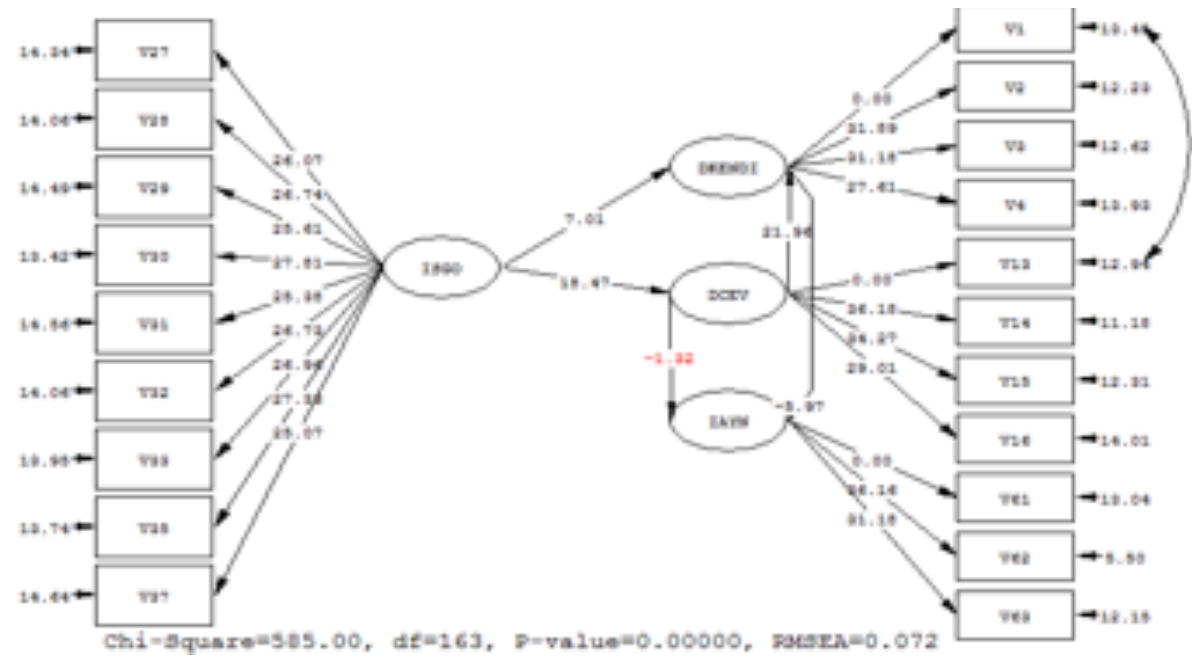

Şekil 3. Işsgören Odakı Liderlik Tarzına Yönelik Olumlu Duygu Iklimine Iilişkin Yapısal Model ve t Değerleri

Gizil değiş̧kenlerle gözlenen değişkenler arasındaki ilişkiler ya da gözlenen değişkenlerin gizil değişkenlerde ilişkilendikleri varyanslar da incelenmiştir. $\mathrm{Bu}$ ilişkiler sadece Model 1 açıklanmıştır. Çünkü araştırmanın amacı direk ilişkiler yerine gizil değişkenler arasındaki ilişkileri incelemektir. Gizil değişkenlerle gözlenen değişkenler arasındaki korelasyonlar ilişkileri vermektedir. Bu ilişkilerin karesi ise gizil değişkendeki varyansı göstermektedir. Bu varyans değeri hata terimlerine bağlı olarak da bulunabilmektedir. Bunun için her bir değişkene ait hata terimini birden çıartmak gerekmektedir.

İşgören odaklı liderlik algılamalarında en yüksek ilişkiye sahip gözlenen değişken 0,93 birimlik bir ilişki ile "V30" (Güven vericidir) ve "V35" (Astlarına adil davranır) değişkenlerinde elde edilmiştir. Bu değişkenler işgören odaklı liderlik gizil değişkeninde 0,87 birimlik bir varyansla ilişkilenmiştir. En az ilişki ise 0,88 birimlik bir ilişki ile "V37" (Esnektir ve değişime açıktır) değişkeninde elde edilmiştir. V37 değişkeni işgören odaklı liderlik gizil değişkeninde 0,77 birimlik bir varyansla ilişkilenmiştir.

İşörenlerin kendilerinin algıladığı olumlu duygu iklimlerine yönelik gözlenen değişkenlerden en yüksek ilişki 0,92 birimlik bir ilişki ile "V2" (Dayanışma) gözlenen değişkeninde elde edilmiştir. V2 değişkeni olumlu duygu iklimi gizil değişkeninde 0,84 birimlik bir varyansla ilişkilenmiştir. En az ilişkilenen gözlenen değişken ise 0,86 birimlik bir ilişki ile "V4" (Sevinç) değişkeninde elde edilmiştir. V4 değişkeni olumlu duygu iklimi gizil değişkeninde 0,74 birimlik bir varyansla ilişkilenmiştir. Şekil l'e göre duygu iklimleri gizil değişkenlerinin "V1" (umut) ile "V13" (umut) değiş̧kenlerine yanıtlayıcıların verdikleri yanıtlara göre aynı algıyı ölçtükleri, diğer bir deyiş̧le "V1" ile "V13" değişkenlerinin algılanması aynı şekilde olmuştur. Bu iki değişkenin birimlerde aynı özelliği ölçmekte olduğundan ilgili değişkenlerde modifikasyona gidilmiştir.

İşgörenlerin, çevresinin algıladığı olumlu duyguları gizil değişkeninde en yüksek ilişki 0,94 birimlik bir ilişki ile "V14" (Dayanışma) değişkeninde elde edilmiştir. V14 gözlenen değişkeni çevresinin algıladığ1 olumlu duyguları gizil değişkeninde 0,88 birimlik bir varyansla ilişkilenmiştir. En az varyansla ilişkilenen değişken ise, "V16" (Sevinç) değişkeni olduğu belirlenmiştir.

İşgörenlerin işten ayrılmaya yönelik gizil değişkeninde en yüksek ilişki 0,97 birim ile "V62" (Son bir yıl içerisinde işimden ayrılmayı daha sık düşünmeye başladım) gözlenen değişkeninde elde edilmiştir. V62 değişkeni işten ayrılmaya yönelik gizil değişkeninde 0,94 birimlik bir varyansla ilişkilenmiştir. En az ilişkilenen değişken ise 0,89 birimlik bir ilişki ile "V61" 
(Eğer imkanım olsaydı işimden ayrılırdım) değişkeninde elde edilmiştir. V61 değişkeni 0,79 birimlik bir varyansla ilişkilenmiştir. Sonuçlar Şekil 2'de verilmiştir.

Gizil değişkenlerin incelenmeye devam edildiği ve kabul edilen yeni model 2 Şekil 4 ve Şekil 5 'te verilmiştir. Araştırmada kurulan yapısal eşitlik modeli 2'nin sinanmasinda elde edilen uyum ölçütleri; $\chi^{2}=518$; d.f. $=145 ; \chi 2 / d f=3,58$, P-value $=0,0000$ RMSEA=0,072, $\mathrm{NFI}=0.98, \quad \mathrm{NNFI}=0.99, \quad \mathrm{PNFI}=0,84, \quad \mathrm{CFI}=0.99$, $\mathrm{IFI}=0.99, \mathrm{RFI}=0.98, \mathrm{GFI}=0.90, \mathrm{RMR}=0.057$ olarak elde edilmiştir. Uyum ölçütleri elde edilen modelin kabul edilebilir olduğunu göstermektedir.
Buna göre duygu iklimi gizil değişkenin görev odaklı liderlik tarzı ile işten ayrılma niyeti arasında aracı rolünün olup olmadığının araştırıldığı yeni modele göre;

Çalışanların kendilerinin algıladığı olumlu duygu iklimi, görev odaklı liderlik algılamaları ile işten ayrilma niyetleri arasında aracı rol üstlenip üstlenmediği de araştırılmış çalışanların kendilerinin algıladığı olumlu duygu ortamının aracı özelliğe sahip olduğu belirlenmiştir. Dolayısıyla $\mathbf{H}_{3}$ desteklenmiştir.

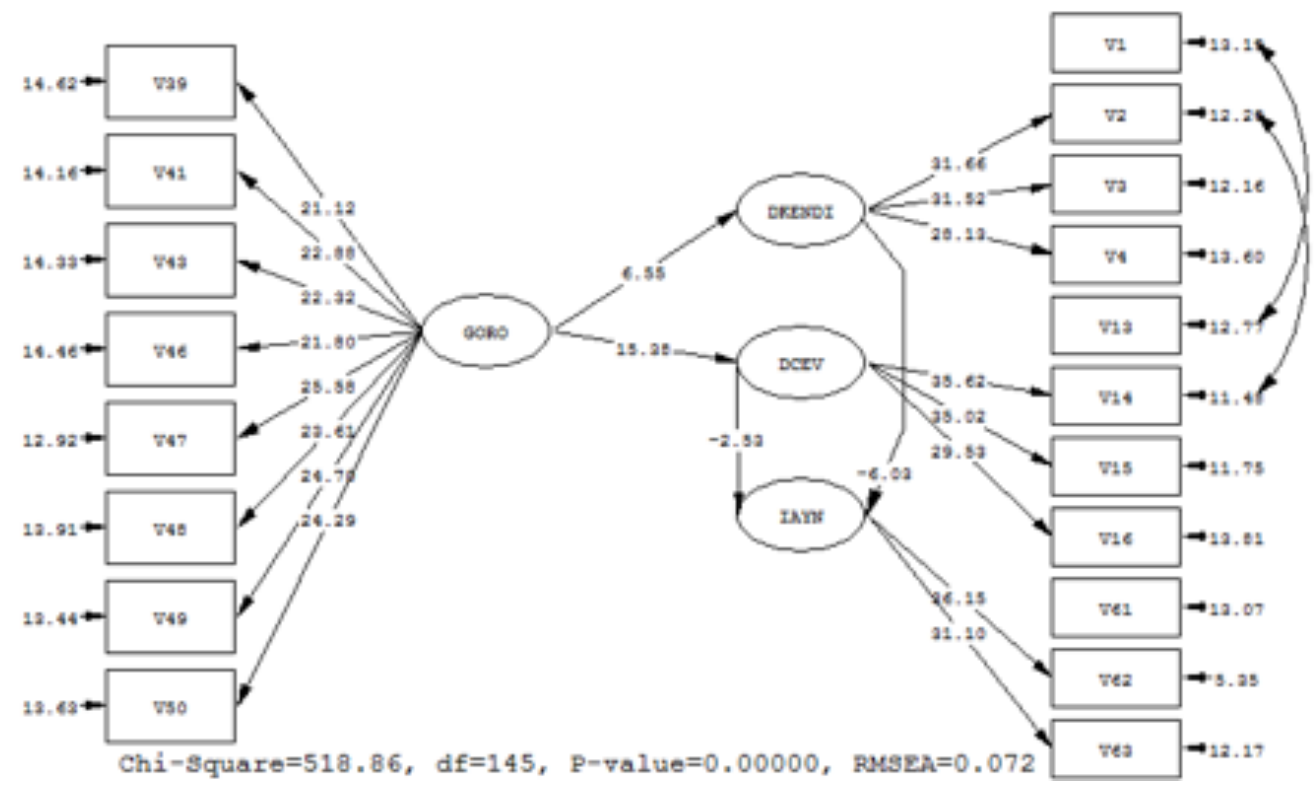

Şekil 4. Görev Odakı Liderlik Tarzına Yönelik Olumlu Duygu İklimine Ilişkin Yapısal Model ve t Değerleri

İşten ayrılma niyetine yönelik kurulabilecek regresyon modeli de;
IAYN $=-0.58^{\star}$ DKENDI- $0.24^{\star}$ DCEV şeklinde yazılabilir. Model 2 için elde edilen yollara ait ilişki grafiği Şekil 5’te verilmiştir. 


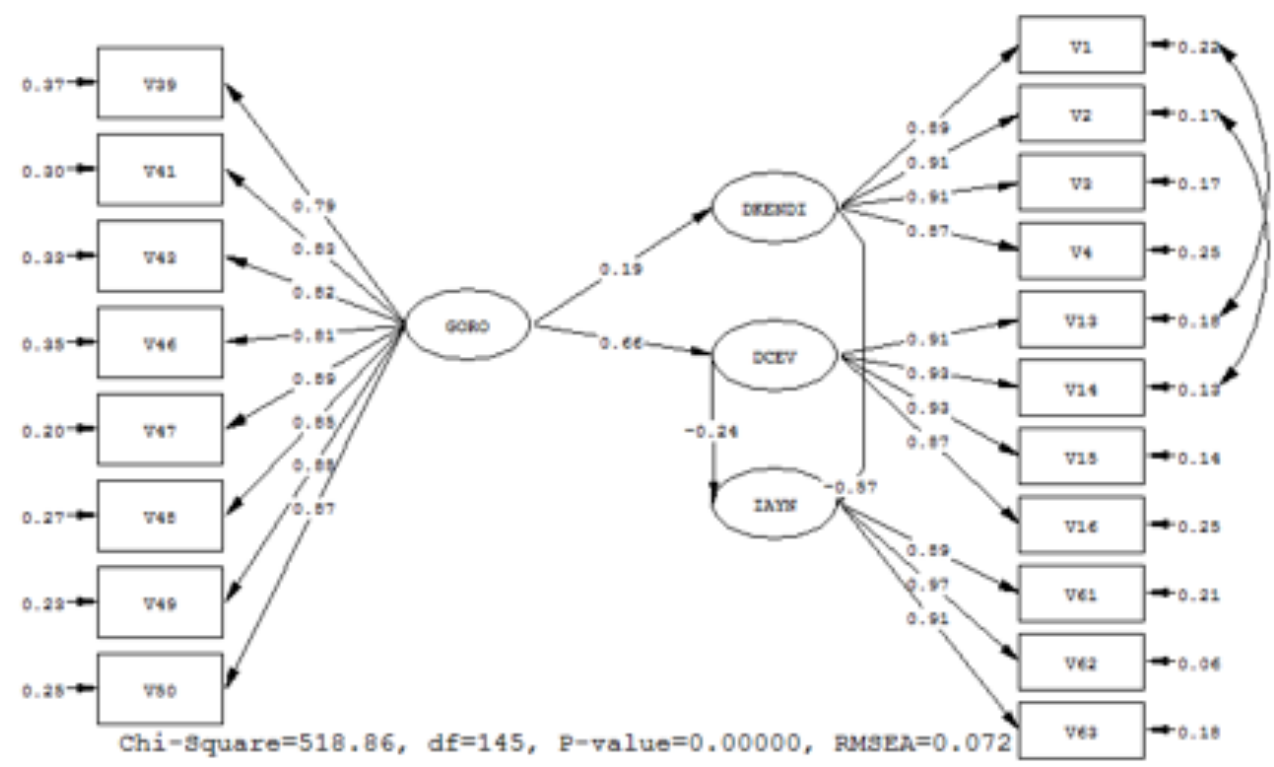

Şekil 5. Görev Odakıı Liderlik Tarzına Yönelik Olumlu Duygu Iklimine Illişkin Yapısal Model ve Yol Ilişskileri

Olumlu duygu iklimine ilişkin oluşturulan son modelde değişim odaklı liderlik tarzı ile işten ayrılma niyeti yönelik aracılık ilişkisi araştırılmıştır. Modele yönelik elde edilen uyum ölçütleri; $\chi 2=611,38$; d.f. $=145 ; \chi 2 / \mathrm{df}=4,21, \mathrm{P}$-value $=0,0000 \mathrm{RMSEA}=0,080$,
NFI $=0.98, \quad$ NNFI $=0.99, \quad$ PNFI $=0,83, \quad$ CFI $=0.99$, $\mathrm{IFI}=0.99, \mathrm{RFI}=0.98, \mathrm{GFI}=0.89, \mathrm{RMR}=0.068$ olarak elde edilmiştir. Uyum ölçütlerine bakıldığında elde edilen modelin kabul edilebilir olduğunu göstermektedir. Model 3, Şekil 6 ve Şekil 7’de verilmiştir.

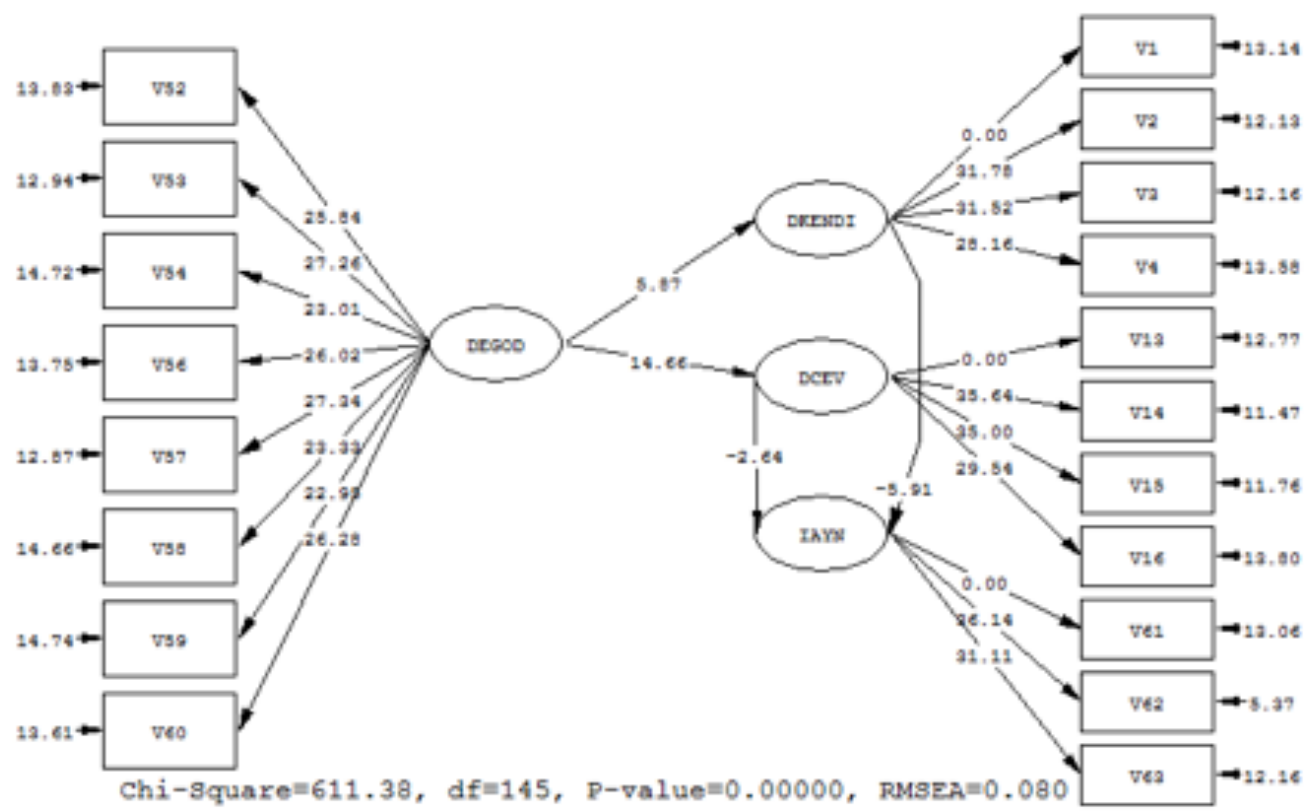

Şekil 6. Değiş̧im Odaklı Liderlik Tarzına Yönelik Olumlu Duygu İklimine İlişkin Yapısal Model ve t Değerleri 
Model 3'e göre elde edilen yapısal eşitlik modeline göre;

Çalışanların kendilerinin algıladığı olumlu duygu iklimi, değişim odaklı liderlik algılamaları ile işten ayrılma niyetleri arasında aracı rol üstlenip üstlenmediği de araştırılmış çalışanların kendilerinin algıladığ olumlu duygu ortamının aracı özelliğe sahip olduğu belirlenmiştir. Dolayısıyla $\mathbf{H}_{4}$ desteklenmiştir.
Model 3'e yönelik elde edilen $t$ istatistikleri ve yol grafiği Şekil 6'da ilişki grafiği de Şekil 7'de verilmiştir. Çalışanların Model 3'e göre ișten ayrılma niyetine yönelik kurulabilecek regresyon modeli de; IAYN= - $0.56^{\star}$ DKENDI $-0.25^{\star}$ DCEV şeklinde yazılabilir.

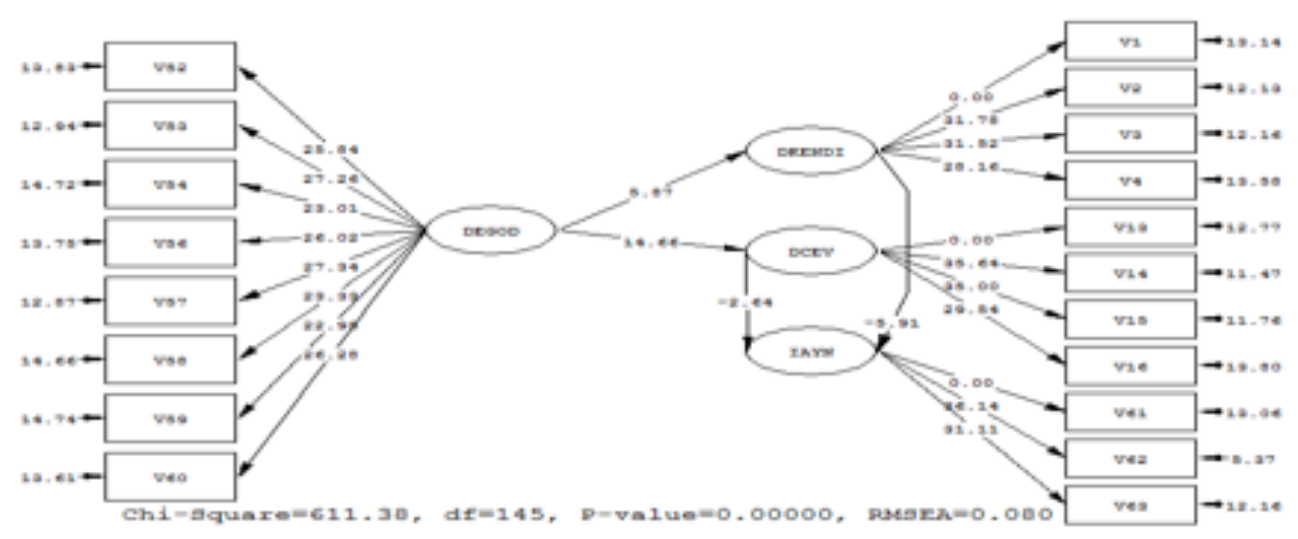

Şekil 7. Değişim Odakı Liderlik Tarzına Yönelik Olumlu Duygu İklimine ilişkin Yapısal Model ve t Değerleri

Olumsuz duygu iklimine yönelik oluşturulan ilk modelde duygu iklimi, işgören odaklı liderlik tarzı ve işten ayrılma niyeti arasındaki aracılık etkisine yönelik ilişkiler araştırılmıştır. Modele yönelik elde edilen uyum ölçütleri; $\chi 2=1609,09 ;$ d.f. $=343 ; \chi 2 /$ $\mathrm{df}=4,69, \mathrm{P}$-value $=0,0000$ RMSEA $=0,086$, NFI $=0.98$, NNFI $=0.98, \quad$ PNFI $=0,89, \quad$ CFI $=0.98, \quad$ IFI $=0.98$, $\mathrm{RFI}=0.98, \mathrm{GFI}=0.78, \mathrm{RMR}=0.11$ olarak elde edilmiştir. Uyum ölçütlerine bakıldığında atık ortalamalarının kareköküne dayanan RMR değerinin 0,08'den daha büyük olduğu gözlenmiştir. RMR değeri 0 ile 1 arasında değerler almasına rağmen 0,08 'den büyük hesaplanması istenen bir durum değildir. Diğer bilgi kriterleri kabul edilebilir olduğundan modelin uyumu uygun olduğu kabul edilmiştir. Model 4, Şekil 8 ve Şekil 9'da verilmiştir.

Buna göre olumsuz duygu iklimi gizil değişkenin işgören odaklı liderlik tarzı ile işten ayrılma niyeti arasında aracı rolünün olup olmadığının araştırıldığı model 4'e göre;

- İşgörenlerin, kendilerinin algıladığı olumsuz duygu iklimi, işgören odaklı liderlik algılamaları ile işten ayrılma niyetleri arasında aracı rol üstlendiği belirlenmiş ve $\mathbf{H}_{5}$ desteklenmiştir.

- İşgörenlerin çevresinin algıladığı olumsuz duygu iklimi, işgören odaklı liderlik algılamaları ile işten ayrılma niyetleri arasında aracı rol üstlendiği belirlenmiştir. Dolayısıyla $\mathbf{H}_{6}$ desteklenmiştir.

Model 4'e yönelik elde edilen $t$ istatistikleri ve yol grafiği Şekil 8'de ilişki grafiği de Şekil 9'da verilmiştir. Çalışanların Model 4'e göre işten ayrılma niyetine yönelik kurulabilecek regresyon modeli de; IAYN= $\mathbf{0 . 6 8}^{\star}$ DKENDIO + $\mathbf{0 . 1 6}^{\star}$ DCEVO şeklinde yazılabilir. 


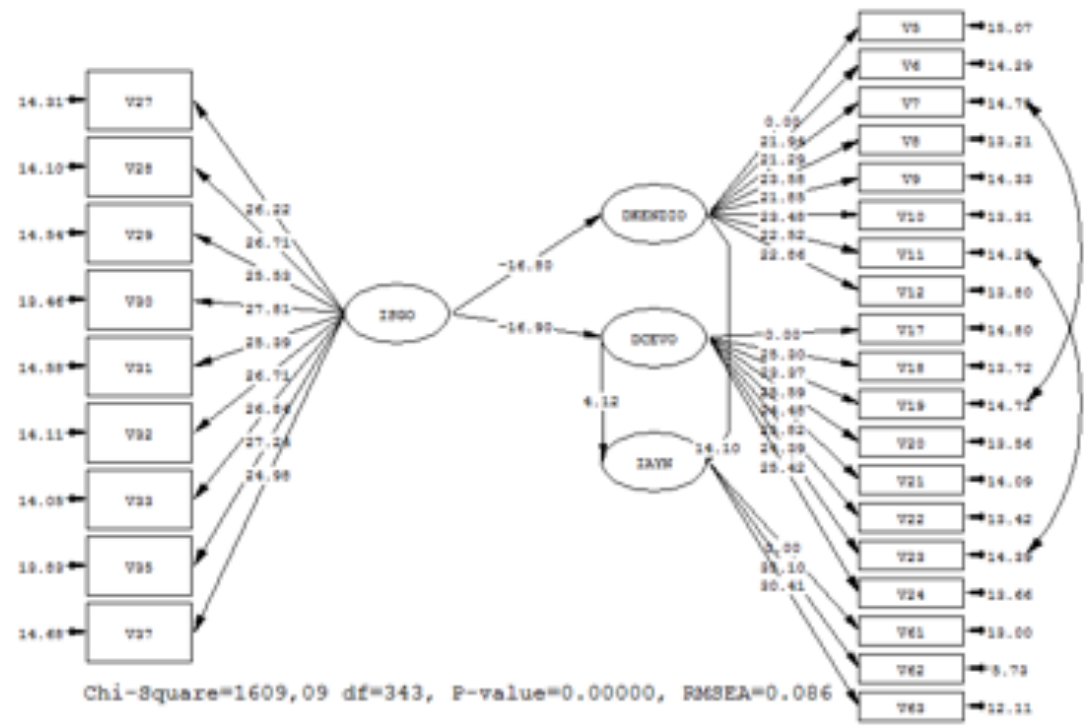

Şekil 8. İşören Odaklı Liderlik ve Olumsuz Duygu İkliminin İsten Ayrılmaya IIlişkin Yapısal Model ve t İstatistikleri

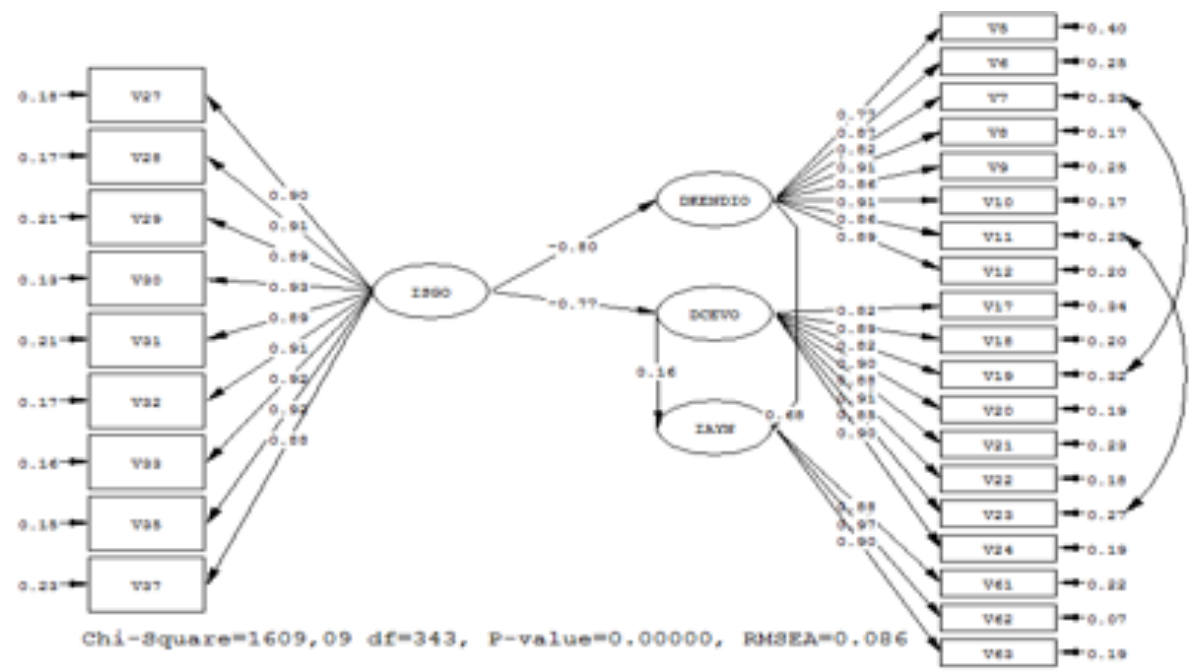

Şekil 9. İşgören Odakı Liderlik ve Olumsuz Duygu İkliminin Işsten Ayrılmaya Ilişkin Yol Grafiği ve İlişkileri

Olumsuz duygu iklimine yönelik oluşturulan ikinci modelde duygu iklimi, görev odaklı liderlik tarzı ve işten ayrılma niyeti arasındaki aracılık etkisine yönelik ilişkiler araştırılmıştır. Modele yönelik elde edilen uyum ölçütleri; $\chi 2=1566.68$; d.f. $=317 ; \chi 2$ / $\mathrm{df}=4,94, \mathrm{P}$-value $=0,0000 \mathrm{RMSEA}=0,089, \mathrm{NFI}=0.98$,
NNFI $=0.98, \quad$ PNFI $=0,88, \quad$ CFI $=0.98, \quad$ IFI $=0.98$, RFI $=0.98$, GFI $=0.81, \mathrm{RMR}=0.053$ olarak elde edilmiştir. Uyum ölçütlerine bakıldığında kabul edilebilir olduğundan modelin uyumu uygun olduğu kabul edilmiştir. Model 5, Şekil 10 ve Şekil 11'de verilmiştir. 


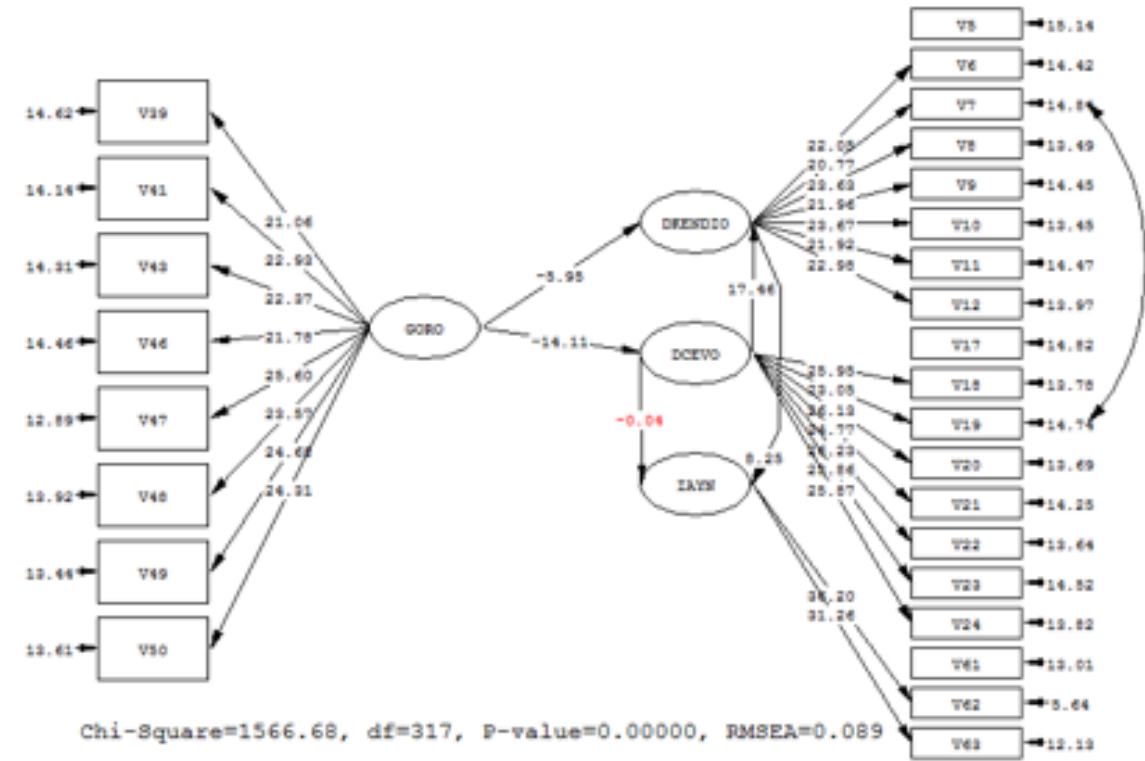

Şekil 10. Görev Odakı Liderlik ve Olumsuz Duygu İkliminin İșten Ayrılmaya İlişkin Yol Grafiği ve t İstatistikleri

Buna göre olumsuz duygu iklimi gizil değişkenin görev odaklı liderlik tarzı ile işten ayrılma niyeti arasında aracı rolünün olup olmadığının araştırıldığı model 5’e göre;

- İşgörenlerin, kendilerinin algıladığı olumsuz duygu iklimi, değişim odaklı liderlik algılamaları ile işten ayrılma niyetleri arasında aracı rol üstlendiği belirlenmiş ve $\mathbf{H}_{7}$ desteklenmiştir.
- İşgörenlerin, çevresinin algıladığg olumsuz duygu iklimi, değişim odaklı liderlik algılamaları ile işten ayrılma niyetleri arasında aracı rol üstlenmesine yönelik yeterli kanıt elde edilemediğinden $\mathbf{H}_{8}$ desteklenememiştir. İşten ayrılma niyetine yönelik yapısal model de aşağıdaki gibi yazılabilir.

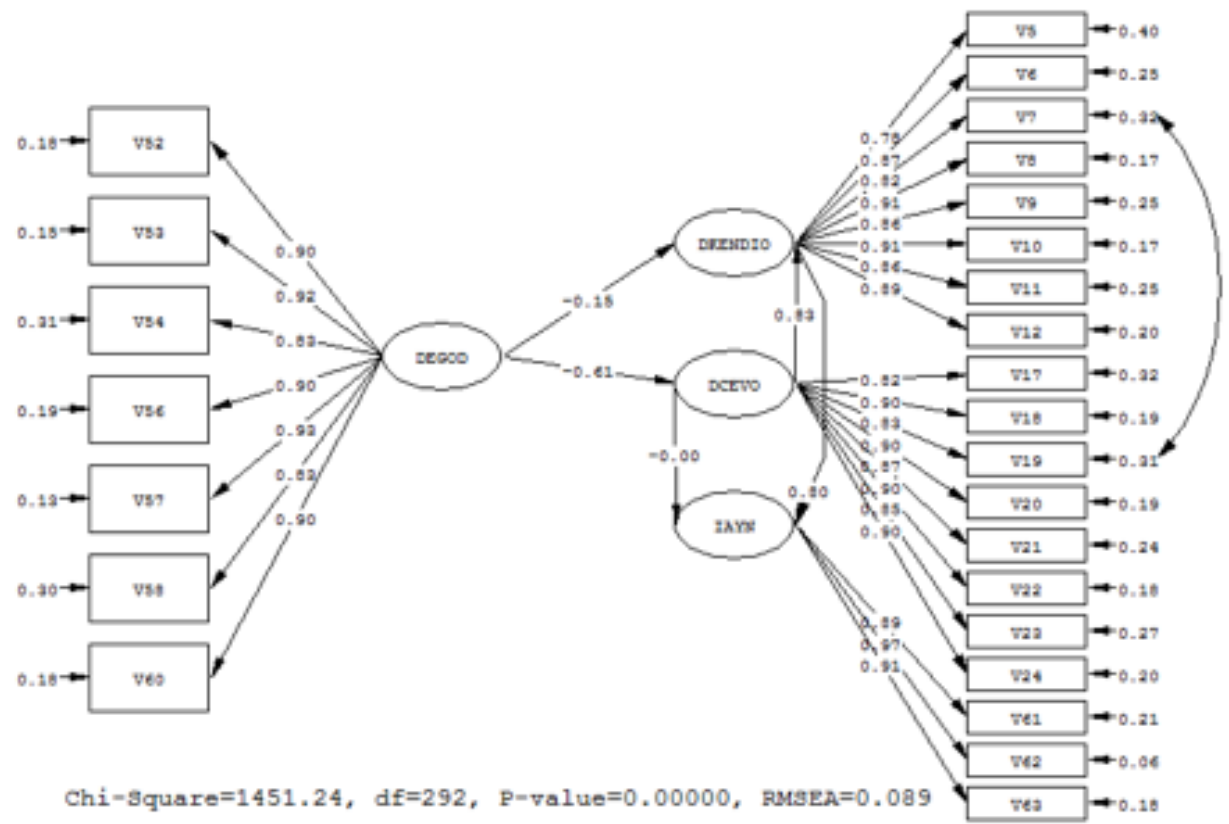

Şekil 11. Değişim Odakı Liderlik ve Olumsuz Duygu İkliminin İşten Ayrılmaya İlişkin Yol Grafiği ve İlişkileri 
Model 5'e yönelik elde edilen $t$ istatistikleri ve yol grafiği Şekil 10'da ilişki grafiği de Şekil 11'de verilmiştir. Çalışanların Model 5’e göre işten ayrılma niyetine yönelik kurulabilecek regresyon modeli de; IAYN= $0.76^{\star}$ DKENDIO $+0.042^{\star}$ DCEVO şeklinde yazılabilir.

Olumsuz duygu iklimine yönelik oluşturulan son modelde değişim odaklı liderlik tarzı, işgörenlerin kendi algıladığı olumsuz duygu iklimi ile işten ay- rılma niyetine yönelik aracılık etkisi ilişkileri araşt1rılmıştır. Modele yönelik elde dilen uyum ölçütleri; $\chi 2=1451,24 ; \quad$ d.f. $=292 ; \chi 2 / d f=4,97, P$-value $=0,0000$ RMSEA $=0,089, \mathrm{NFI}=0.98, \mathrm{NNFI}=0.98, \mathrm{PNFI}=0,88$, $\mathrm{CFI}=0.98, \mathrm{IFI}=0.98, \mathrm{RFI}=0.98, \mathrm{GFI}=0.81, \mathrm{RMR}=0.058$ olarak elde edilmiştir. Uyum ölçütlerine bakıldığında kabul edilebilir olduğundan modelin uyumu uygun olduğu kabul edilmiştir. Model 6, Şekil 12 ve Şekil 13 'te verilmiştir.

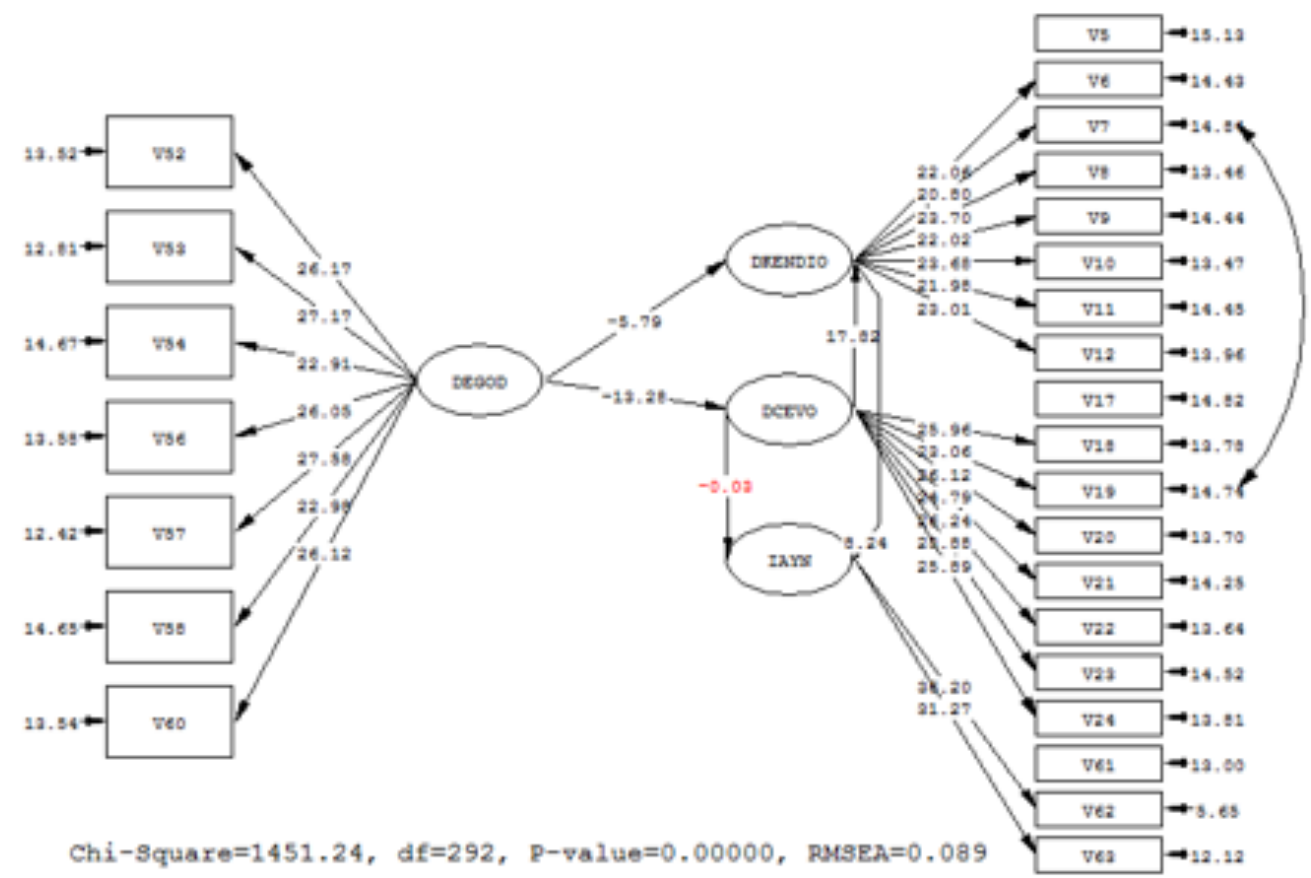

Şekil 12. Değişim Odakı Liderlik ve Olumsuz Duygu İkliminin İșten Ayrılmaya Ilişkin Yol Grafiği ve t İstatistikleri

Buna göre olumsuz duygu iklimi gizil değişkenin değişim odaklı liderlik tarzı ile işten ayrılma niyeti arasında aracı rolünün olup olmadığının araştırıldığı model 6'e göre;

- İşgörenlerin, kendilerinin algıladığı olumsuz duygu iklimi, değişim odaklı liderlik algılamaları ile işten ayrılma niyetleri arasında aracı rol üstlendiği belirlenmiş ve $\mathbf{H}_{9}$ desteklenmiştir.

- İşgörenlerin, çevresinin algıladığı olumsuz duygu iklimi, değişim odaklı liderlik algılamaları ile işten ayrılma niyetleri arasında aracı rol üstlenmesine yönelik yeterli kanıt elde edilemediğinden $\mathrm{H}_{10}$ desteklenememiştir.

Model 6'ya yönelik elde edilen $t$ istatistikleri ve yol grafiği Şekil 12'de ilişki grafiği de Şekil 13’te verilmiştir. Çalışanların Model 6’e göre işten ayrılma niyetine yönelik kurulabilecek regresyon modeli de; IAYN= $0.75{ }^{*}$ DKENDIO $+0.043^{*}$ DCEVO şeklinde yazılabilir. 


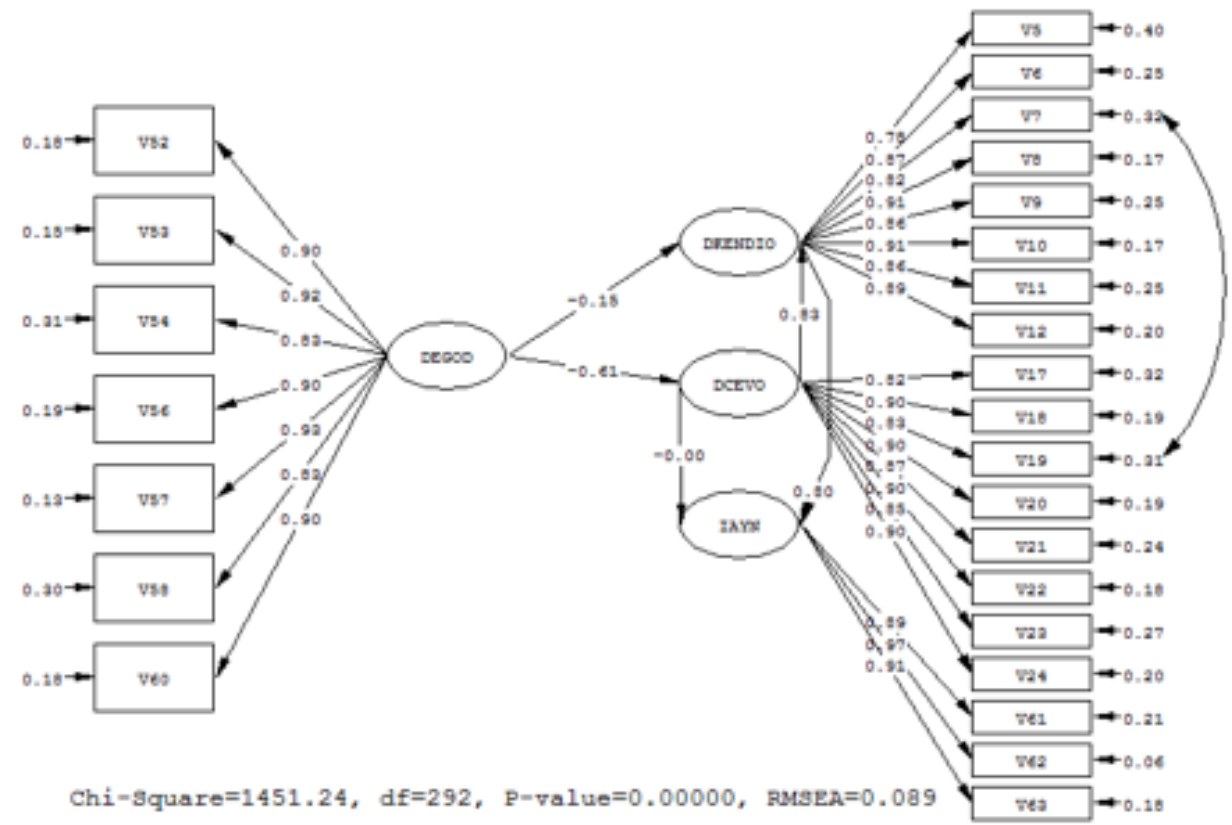

Şekil 13. Değişim Odakı Liderlik ve Olumsuz Duygu İkliminin İsten Ayrılmaya Ilişsin Yol Grafiği ve Illişsileri

\section{Sonuç ve Değerlendirme}

Araştırmada farklı altı model üretilmiş ve test edilmiştir. Modelde gizil değişkenler arasında olası ilişkiler de dikkate alınarak farklı modeller denenmiştir. Sonuç olarak liderlik tarzlarının tek tek ele alınarak duygu iklimine olan etkileri ve olumlu ya da olumsuz duygu ikliminin işten ayrılmaya nedensel olabilecek aracılık ilişkileri kurulan modeller ile test edilmiştir.

İlk modelde, turizm işletmelerinde işgörenlerin kendilerinin algıladığı olumlu duygu iklimi, işgören odaklı liderlik algılamaları ile işten ayrılma niyetleri arasında kısmi aracılık rolü bulunmuştur. Buna göre; işgören odaklı liderlik tarzı işten ayrılma niyetini doğrudan etkilediği gibi duygu iklimi üzerinden dolaylı etkilediği söylenebilir. Spiess (2011) sağl1k/ hizmet sektöründe duygu iklimiyle ilgili benzer bir çalışmada işgören odaklı liderlik tarzıyla duygu iklimi arasında anlamlı bir ilişki bulmuştur. Bu modelin anlamlı çıkmasını işgören odaklı liderlik tarzının astlarının rolünü ve görevlerini tanımlamasıyla, onlara örgütsel amaçlara ulaşma yollarında yardımcı olmasıyla ve amaca ulaşıldığında olumlu geri besleme yoluyla ödüller vermesiyle açıklanabilir. Ayrıca; Özer
(2007) sağlık sektöründe yapmış olduğu çalışmada işgören odaklı liderlik tarzının işten ayrılma niyetiyle ters yönlü ilişkisi olduğunu bulmuştur. Turizm işletmelerinde işgörenlerin çevrelerinin algiladığı olumlu duygu iklimi, işgören odaklı liderlik algılamaları ile işten ayrılma niyetleri arasında kısmi aracılık rolü hipotezi de doğrulanamamıştır. Bunu işgörenin kendi içinde yaşadığı koşulları bildiği için kişi, kendi işten ayrılma niyetinin olup olmadığını bilir; ancak, çevresindeki insanların örgüt içindeki iklimi olumsuz olarak algılasalar bile diğer kişilerin yaşadığı ekonomik koşulları, medeni durumu, aile faktörü vb. tam olarak kestirememesi nedeniyle işten ayrılma niyetinin olup olmadığını bilememesiyle açıklayabiliriz.

Araştırmanın ikinci modelinde, turizm işletmelerinde işgörenlerin kendilerinin algiladığ gu iklimi, görev odaklı liderlik algılamaları ile işten ayrilma niyetleri arasında kısmi aracılık rolü tespit edilmiştir. Buna göre; görev odaklı liderlik tarzının işten ayrılma niyetini doğrudan etkilediği gibi duygu iklimi üzerinden dolaylı etkilediği söylenebilir. Aynı zamanda işgörenlerin çevrelerinin algıladığı olumlu duygu iklimi, görev odaklı liderlik algılamaları ile 
işten ayrılma niyetleri arasında kısmi aracılık rolü bulunmuştur. Görev odaklı liderlik tarzıyla işten ayrılma niyeti arasında duygu ikliminin aracılık etkisi daha önce başka bir araştırmada incelenmemiştir. Görev odaklı liderlik tarzının doğrudan işten ayrılma niyetine etkisini araştıran bir araştırmada görev odaklı liderlik tarzının işten ayrılma niyetini artırdığı sonucu elde edilmiştir (Özer 2007). Görev odaklı liderlik tarzının hem işgörenin duygu iklimine ilişkin kendi algısı hem de çevresinin duygu iklimi algılaması üzerinde olumlu ve anlamlı etkisinin çıkmasını; farklı sosyo-kültürel yapılardan ve farklı departmanlarda çalışan işgörenlerin denetleyici, kimin neden sorumlu olduğunu bilen, tutarlı, planları dikkatli yapan ve her işgörene görevini yaptı̆̆ sürece eşit davranan liderlerin işgörenler tarafından adil bir yönetim tarzı olarak algılamasıyla açıklayabiliriz.

Araştırmanın üçüncü modelinde, turizm işletmelerinde işgörenlerin kendilerinin algıladığg olumlu duygu iklimi, değişim odaklı liderlik algılamaları ile işten ayrılma niyetleri arasında kısmi aracılık rolü bulunmuştur. Buna göre; değişim odaklı liderlik tarzının işten ayrılma niyetini doğrudan etkilediği gibi duygu iklimi üzerinden dolaylı etkilediği söylenebilir. Aynı zamanda işgörenlerin çevrelerinin algıladığı olumlu duygu iklimi ve görev odaklı liderlik algılamaları ile işten ayrılma niyetleri arasında kısmi aracilık rolü bulunmuştur. Bu araştırmanın sonucu da Spiess (2011)'in yapmış olduğu araştırma sonucuyla paralellik göstermektedir. Yeni fikirleri teşvik eden, gelecek hakkında planlar yapan, çatışmaları ortadan kaldıracak olanaklar yaratan ve işlerin uygulanmasında yeni ve değişik fikirler ortaya koyan liderlerin örgüt içerisinde olumlu duygu iklimleri yarattıkları gözlemlenmiştir.

Araştırmanın dördüncü, beşinci ve altıncı modelinde işgören odaklı, görev odaklı ve değişim odaklı liderlik algılamaları ile olumsuz duygu iklimine ilişkin kendi ve çevresinin algılamalarının işten ayrılma niyeti üzerindeki aracilık etkileri incelenmiştir. Turizm işletmelerinde işgörenlerin kendilerinin algıladığı olumsuz duygu iklimi, işgören odaklı, görev odaklı ve değişim odaklı liderlik algılamaları ile işten ayrılma niyetleri arasında kısmi aracılık rolü tespit edilmiştir. Buna göre; üç liderlik tarzı da işten ayrılma niyetini doğrudan etkilediği gibi duygu iklimi üzerinden dolaylı etkilediği de söylenebilir. Ancak, işgörenin çevresinin algıladığı olumsuz duygu iklimi, görev odaklı ve de- ğişim odaklı liderlik algılamaları ile işten ayrılma niyetleri arasında kısmi aracılık rolü hipotezleri doğrulanamamıştır. Bunun daha önce de belirttiğimiz gibi işgörenin kendi içinde yaşadığı koşulları bildiği için, kendi işten ayrılma niyetinin olup olmadığını bilir; ancak, çevresindeki insanların örgüt içindeki iklimi olumsuz olarak algılasalar bile diğer kişilerin yaşadığ ekonomik koşulları, medeni durumu, aile faktörü vb. tam olarak kestirememesi nedeniyle işten ayrılma niyetinin olup olmadığını bilememesiyle açıklanabilir.

Sonuç olarak duygu iklimlerinin liderlik tarzları ile işten ayrılma niyeti arasında aracılık etkisinin olduğu bulunmuştur. Günümüzde turizm işletmelerinde yapılan araştırmalarda değişim odaklı liderlik tarzının biraz daha ön planda olmasına rağmen, duygu ikliminin şekillenmesinde lider hangi tarzı benimserse benimsesin önemli olanın lider ile geliştirilen ilişkinin karşılıklı güven, sevgi, saygıya dayanması noktasidır.

Yapılan araştırmada demografik özellikleri incelendiğinde işgörenlerin çoğunluğunun eğitim durumunun ortaöğretim düzeyinde olduğu, sektörde çalışma yaşının oldukç̧a genç (27) olduğu, işgörenlerin kurumdaki çalışma sürelerinin (kıdem) oldukça düşük olduğu, ayrıca işgörenlerin turizm meslek kıdemlerinin de düşük olduğu görülmektedir. Bu araştırma sonucu Şahin (2007); Ceseroğlu (2010)'nun yapmış olduğu araştırma sonuçlarıyla paralellik göstermektedir. $\mathrm{Bu}$ da emek-yoğun olan turizm sektöründe işgören devir hızının yüksek olduğunu, işgörenlerin genç yaşlarda turizm sektöründe çalıştı̆̆ını, ayrıca turizm sektörünün yoğun çalışma yapısı itibariyle ileri yaşlarda çaıışmaya müsait olmadığını göstermektedir.

\section{Öneriler \\ Uygulayıcılara Öneriler}

Turizm işletmesinde liderlik tarzının duygu iklimini ve işten ayrılma niyetini olumlu yönde etkilediği görülmektedir. $\mathrm{Bu}$ nedenle liderler mutlaka örgüt içerisindeki hangi duygu ikliminin hakim olduğunu kestirebilmeli, bu durumun işgörenlerin örgütten ayrılma niyetini etkileyeceğini unutmamalıdırlar. Buna bağlı olarak turizm işletmelerinde yöneticilerin değişen sabit bir liderlik tarzı içinde yer almamaları o günün şartlarına yapısına bağlı olarak bir liderlik tarzı uygulamalarını önermek yanlış olmayacaktır. Örgüt içerisinde liderin kendisini sürekli geliştirebilmesi; 
ayrıca işgörenlerin daha üretken olması ve çalışmalarında uzmanlaşması için onlara önayak olmalı, yeri geldiğinde ise yol göstermelidir. Sadece ișletmenin geleceğini düșünmeyip, işgörenlerin geleceğini de düşünmeli ve "Örgütteki işgörenler geçici" mant1ğıla hareket etmemelidir. Liderler, işgörenlere zamana ayak uydurabilmesi için gerekli olan eğitim ve seminerlere gitmesi yönünde olanaklar sağlamalıdır. Gerektiği takdirde, kendisinin de bu kurslara katılip çalışanlarına ayak uydurması gerekmektedir.

\section{Araştırmacılara Öneriler}

$\mathrm{Bu}$ araştırmada turizm işletmesi işgörenlerinin duygu iklimi ve liderlik tarzı tarafından etkilenen örgütsel sonuç değişkenleri olarak işten ayrılma niyeti ele alınmıştır. Araştırmacılar işten ayrılma niyeti dışında tükenmişlik, yabancılaşma iş tatmini, motivasyon vb. başka duygu temelli sonuç değişkenlerini bağımlı değişken olarak alıp inceleyebilirler.

$\mathrm{Bu}$ araştırma Alanya ilçesinde turizm sezonunun yeni başladığı bir dönemde gerçekleşmiştir. Alanya'da sezonun yeni açılmış olmasından dolayı işgörenlerde işten ayrılma niyeti düşük çıkmış olabilir. Araştırmacılar benzer araştırmayı sezonun yoğun yaşandığı Haziran, Temmuz ve Ağustos aylarında gerçekleştirirlerse, sezonun yoğun yaşandığ faktörlerde etkileyeceğinden (stres, yoğun çalışma saatleri vb.) farklı sonuçlar elde edilebilir.

\section{Kaynakça}

Akoğlan Kozak, M. (2012). Otel İşletmeciliği. Ankara: Detay Yayıncilık.

Cammann, C., Fichman, M., Jenkins, D. \& Klesh, J. (1979). Michigan Organizational Assessment Questionnaire. Michigan: University of Michigan, Ann Arbor.

Ceseroğlu, C. M. (2010). Örgütlerde İşgören İliş̧kileri Açısından Psikolojik Kontrat ve Örgütsel Bağllık Üzerine Etkisi: 4-5 Yıldızlı Otel İşletmeleri Örneği, Çanakkale Onsekiz Mart Üniversitesi Sosyal Bilimler Enstitüsü, Yüksek Lisans Tezi, Çanakkale.
Cole, S. M., Heike, B. \& Vogel, B. (2006). Emotion as Mediators of the Relations Between Perceived Supervisor Support and Psychological Hardiness on Employee Cynicism, Journal of Organizational Behavior, 27(4), 463-484.

Çelik, S. (2011). Liderlik Tarzları İle Stratejik Kararlar Arasındaki İlişki: İstanbul'daki 4 ve 5 yıldızlı Otel İşletmelerinde Bir Araştırma, Düzce Üniversitesi Sosyal Bilimler Enstitüsü, Yüksek Lisans Tezi, Düzce.

Denision, R. D. (1990). Corporate Culture and Organizational Effectiveness, United States of America: Braun-Brumfield Inc.

De Rivera, J. \& Yurtsever, G. (2010). National Emotional Climate and the Value of Freedom, Beliefs and Values, Springer Publishing Company, 2(1), 57-65.

Eren, E. (2012). Örgütsel Davranış ve Yönetim Psikolojisi. İstanbul: Beta Yayıncılık.

Gök, S. (2009). Örgüt İkliminin Çalışanların Motivasyonuna Etkisi Üzerine Bir Araştırma, Uluslararası İnsan Bilimleri Dergisi, 6(2), 587-605.

Güzel, T. \& Akgündüz, Y. (2011). Liderlik Davranış1nın Orta Düzey Yöneticiler Üzerindeki Etkisi ve Yöneticilerin Tükenmişlik Düzeyleri İle İlişkisi; Kuşadası Otel İşletmelerinde Bir Araştırma, Yönetim Bilimleri Dergisi, 9(2), 281-296.

Güzel, T. (2009). Turizm İșletmelerinde Liderlik. Zeyyat Sabuncuoğlu (Ed.), Turizm İşletmelerinde Örgütsel Davranış içinde (s. 121-134), Bursa: MKM Yayıncilık.

Hicks, G. H., Gullert, C. R. (1981). Organizasyonlar; Teori ve Davranış. Besim Baykal (Çev.), İstanbul: İstanbul Üniversitesi, İşletme Bilimleri Enstitüsü Yayını.

İnce, C. (2013). Demokratik Liderlik ile İhtiyaçlar Hiyerarşisi Arasındaki İliş̧kiye Yönelik 5 Yıldızlı Otel İşletmelerinde Bir Araştırma, Akademik Bakış Dergisi, 35, 1-15. 
Koys, J. D. \& DeCotiis, T. A. (1991). Inductive Measures of Psychological Climate, Human Relations, 44(3), 265-285.

Mullins, L. L. (1998). Managing People in the Hospitality Industry. England: Addison Wesley Longman Limited Edinburg Gate.

Newstorm, W. J. \& Davis, K. (1993). Organizational Behavior (Human Behavior at Work). USA: Mc Graw Hill Inc.

Özer, E. (2007). Akreditasyon Belgesine Sahip Özel Hastanelerdeki Yönetici Hemşirelerin Liderlik Tarzlarının, Hemşirelerinin Liderlik Tarzlarının, Hemşirelerinin İşten Ayrılma Nedenleri Üzerine Etkileri, Marmara Üniversitesi, Yüksek Lisans Tezi, İstanbul.

Paez, D., Basabe, N., Ubillos, S., Gonzalez-Castro, J. L. (2007). Social Sharing, Participation in Demonstrations, Emotional Climate, and Coping with Collective Violence After the March 11th Madrid Bombings, The Society for the Psychological Study of Social Issues, Journal of Social Issues, 63(2), 323-337.

Payne, R. L., Pugh, S. S. (1976). Organizational Structure and Organizational Climate. M.D. Dunnette (Ed.), In Handbook of Industrial and Organizational Psychology, Chicago: Rand Mc Nally College Pub.

Pheysey, C. D. (1993). Organizational Cultures Types and Transformations. London, New York: Routledge.

Riley D. N. (2006). The Effects of Sales Management Leaderships Styles on Salesperson Turnover Intentions, $\mathrm{PhD}$ Thesis, $\mathrm{H}$. Wayne Huizenga School of Business and Entrepreneurship Nova Southeastern University.

Rime, B. (2007). The Social Sharing of Emotion as an Interface Between Individual and Collective Processes in the Construction of Emotional Climates, Journal of Social Issues, 63(2), 307-322.
Robbins, P. S. \& Judge, T. A. (2012). Örgütsel Davranış Organizational Behavior, İnci Erdem (Çev. Ed.), İstanbul: Nobel Kitap.

Ruiz, J. I. (2007). Emotional Climate in Organizations: Applications in Latin American Prisons, Journal of Social Issues, 63(2), 289-306.

Rusbelt, F. \& Rogers, M. (1988). Impact of Exchange Variables on Exit, Voice, Loyalty and Neglect: An Integrative Model of Responses to Decline Job Satisfaction, Academy of Management Journal, 31(2), 599-627.

Schein, H. E. (1999). Sense and Nonsense About Culture and Climate, N. M. Ashkanasy; C. P. M. Wilderom; M. F. Peterson (Ed.), Handbook of Organizational Culture \& Climate, Thousand Oaks: Sage.

Schneider, B. \& Reichers, A. E. (1983). On the Etiology of Climates, Personnel Psychology, 36(1), 19-39.

Smith, D. \& McNeese, K. (1999). The Relationship Between Managerial Motivation, Leadership, Nurse Outcomes and Patient Satisfaction, Journal of Organizational Behavior, 243-259, John Wiley \&amp; Sons.

Smoak L. M. (2008). Dönüştürücü Leadership, WorkRelated Cultural Values And Job Satisfaction, Nova Southeastern University, $\mathrm{PhD}$ Thesis, H. Wayne Huizenga School of Business and Entrepreneurship.

Spiess, J. \& Ashia, K. (2011). The Effect of Emotional Climates in Leader-Follower and Employee-Customer Relationships in a Service Context, Zentralsteller: UZH.

Şahin, F. (2011). Lider-Üye Etkileşimi ile İşten Ayrılma Niyeti Arasındaki İlişki Üzerinde Cinsiyetin Etkisi, Ege Akademik Bakış Dergisi, 11(2), 277-288.

Şahin, N. (2007). Personel Güçlendirmenin İş Tatmini ve Örgütsel Bağlllık Üzerine Etkisi: Dört ve Beş Yıldızlı Otel İşletmelerinde Bir Uygulama, Dokuz Eylül Üniversitesi Sosyal Bilimler Enstitüsü, Doktora Tezi, İzmir. 
Tekin, Y. \& Ehtiyar, R. (2011). Başarının Temel Faktörleri: Vizyoner Liderler, Journal of Yasar University, 24(6), 4007-4023.

Telli, E., Ünsar, A. S. \& Oğuzhan, A. (2012). Liderlik Davranış Tarzlarının Çalışanların Örgütsel Tükenmişlik ve İşten Ayrılma Eğilimleri Üzerine Etkisi: Konuyla İlgili Bir Uygulama, Electronic Journal of Vocational Colleges, 135-150.

Tengilimoğlu, D. (2005). Kamu ve Özel Sektör Örgütlerinde Liderlik Davranışı Özelliklerinin Belirlenmesine Yönelik Bir Alan Çalışması, Elektronik Sosyal Bilimler Dergisi, 4(14), 1-16.

Töremen, F. \& Çankaya, İ. (2008). Yönetimde Etkili Bir Yaklaşım: Duygu Yönetimi, Kurumsal Eğitimbilim Dergisi, 1(1), 33-47.

Tran, V. (1998). The Role of the Emotional Climate in Learning Organizations, The Learning Organization, MCB University Press, 5(2), 99-103.

Tutar, H. \& Altınöz, M. (2007). Örgütsel İklimin İşgören Performansı Üzerine Etkisi: Ostim İmalat İşletmeleri Çalışanları Üzerine Bir Araştırma, Ankara Üniversitesi SBF Dergisi, 65(2), 195-218.

Tütüncü, Ö. \& Akgündüz, Y. (2012). Seyahat Acentalarında Örgüt Kültürü ve Liderlik Arasındaki İlişki: Kuşadası Bölgesinde Bir Araștırma, Anatolia Turizm Araştırmaları Dergisi, 23(1), 59-72.

Unur, K., Çakıcı, C. \& Duran, A. (2011). Otel İşletmelerinde İşgörenlerin Örgütsel Güven Algısı İle İş Memnuniyetleri Arasındaki İlişki Üzerine Dört ve Beş Yıldızlı Şehir Otellerinde Yapılan Bir Araştırma, 12. Ulusal Turizm Kongresi Bildiriler Kitabı, Düzce 30 Kasım-4 Aralık 2011, Akçakoca Turizm İşletmeciliği ve Otelcilik Yüksekokulu, 582-590.
Van de Vijver, F. \& Hambleton, R. (1996). Translating Tests: Somer Practical Guidelines, European Psychologist, 1(2), 89-99.

Whittington, J. L., Goodwin, V. L. \& Murray, B. (2004). Transformational Leadership, Goal Difficulty and Job Design: Independent and Interactive Effects on Employee Outcomes, The Leadership Quarterly, 15, 593-606.

Woo, S. B. (1998). Leader Behaviors and Their Effects on Satisfaction, Commitment, Justice and Organizational Citizenship Behavior in Korean Hotel Employees, Judy Miller (Ed.), Proceedings of Advances in Hospitality and Tourism Research, Kansas State University, 3, 516-528.

Yavuz, E. (2009). İşgörenlerin Dönüşümcü Liderlik ve Örgütsel Bağlllıkla İlgili Tutumlarına Yönelik Bir Araştırma, İşletme Araştırmaları Dergisi, 1(2), 5169.

Yazıcıoğlu, İ. (2009). Konaklama İşletmelerinde İşgörenlerin Örgütsel Güven Duyguları ile İş Tatmini ve İşten Ayrilma Niyetleri Üzerine Bir Alan Araştırması, Elektronik Sosyal Bilimler Dergisi, 8(30), 235-249.

Yeşilyurt, P. (2007). Türk ve İtalyan Yöneticilerinin Liderlik Tarzları: Türkiye'de Faaliyet Gösteren Türkİtalyan Ortak Girişimlerinde Bir Uygulama, Çukurova Üniversitesi Sosyal Bilimler Enstitüsü, Yüksek Lisans Tezi, Adana.

Yurtsever, G. \& De Rivera, J. (2010). Measuring the Emotional Climate of an Organization, Perceptual and Motor Skills, 110(2), 501-516. 